Portland State University

PDXScholar

$11-24-1976$

\title{
The Columbia River as a Barrier to Gene Flow in the Vagrant Shrew, Sorex vagrans vagrans Baird
}

James J. Kirk

Portland State University

Follow this and additional works at: https://pdxscholar.library.pdx.edu/open_access_etds

Part of the Biology Commons

Let us know how access to this document benefits you.

\section{Recommended Citation}

Kirk, James J., "The Columbia River as a Barrier to Gene Flow in the Vagrant Shrew, Sorex vagrans vagrans Baird" (1976). Dissertations and Theses. Paper 2553.

https://doi.org/10.15760/etd.2550

This Thesis is brought to you for free and open access. It has been accepted for inclusion in Dissertations and Theses by an authorized administrator of PDXScholar. Please contact us if we can make this document more accessible: pdxscholar@pdx.edu. 
AN ABSTRACT OF THE THESIS OF James J. Kirk for the Master of Science in Biology presented 24 November 1976.

Title: The Columbia River as a Barrier to Gene Flow in the Vagrant Shrew, Sorex vagrans vagrans Baird

APPROVED BY MEMBERS OF THE THESIS COMMITTEE:

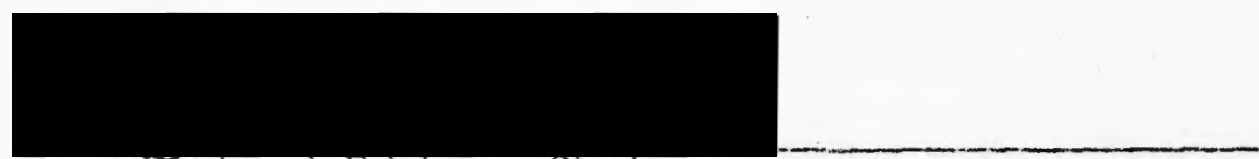

Richard Forbes, Chairman

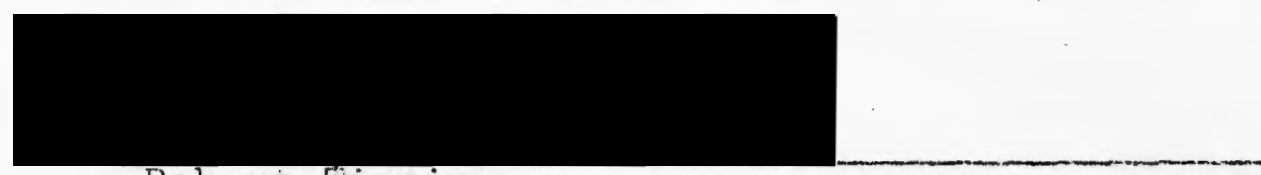

Robert jinnin
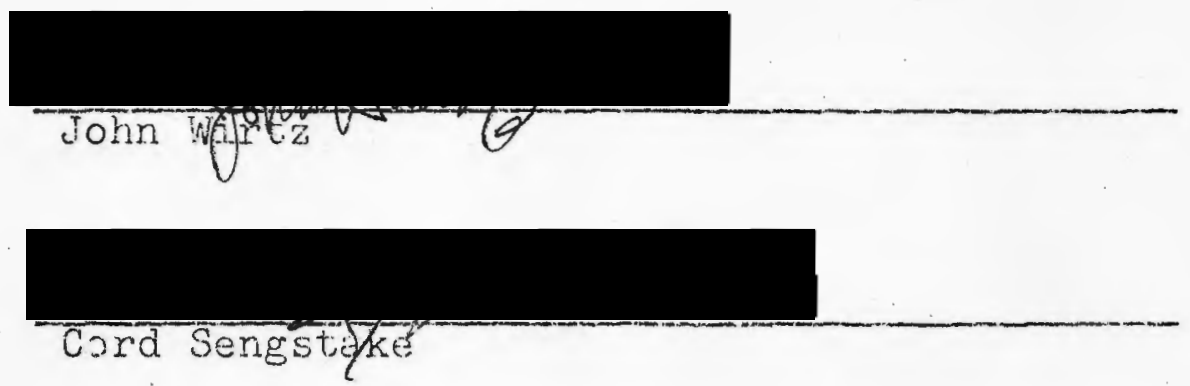

Twenty-one morphological characters were measured in shrews from four islands in the Colurnbia River and Iron the adjecent, Oregon and Washington shores. Infomation on the history and characteristics of the river islards was gathered to facilitate interpretation of the shrev morphology data. Significant differences betwes character means of different populations were detected and average taxonomic distarces between pains of popalations were 
calculated. The Columbia River is an incomplete barrier to gene flow, but its influence has been sufficient to allow divergence of island populations. Natural selection on the small gene pools of island populations has probably contributed to the divergence. Shrews most likely reached the islands from the mainlands by rafting on floating vegetation and debris. Morphometric comparison of island populations seems to provide a more sensitive indication of restricted gene flow than similar comparison of * opposite mainland populations. 
THE COLUMBIA RIVER AS A BARRIER TO GENE FLOW IN THE VAGRANT SHREW, SOREX VAGRANS VAGRANS BAIRD

$$
\text { by }
$$

JAMES J. KIRK

A thesis submitted in partial fulfillment of the requirements for the degree of

\author{
MASTER OF SCIENCE \\ in \\ BIOLOGY
}

Portland State University

1976 
TO THE OFFICE OF GRADUATE STUDIES AND RESEARCH:

The members of the Committee approve the thesis of James J. Kirk presented on 24 November 1976.

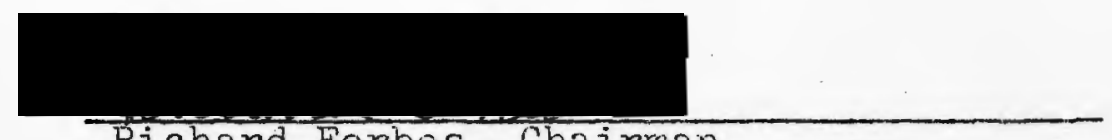

Richard Forbes, Chairman

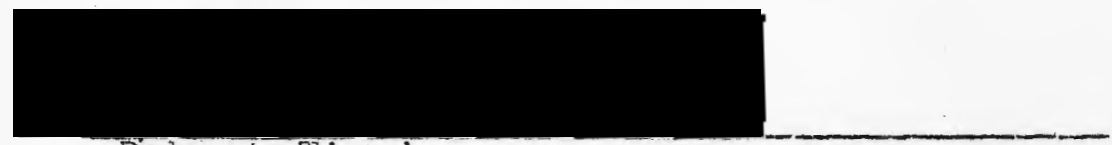

Robert Tinnin
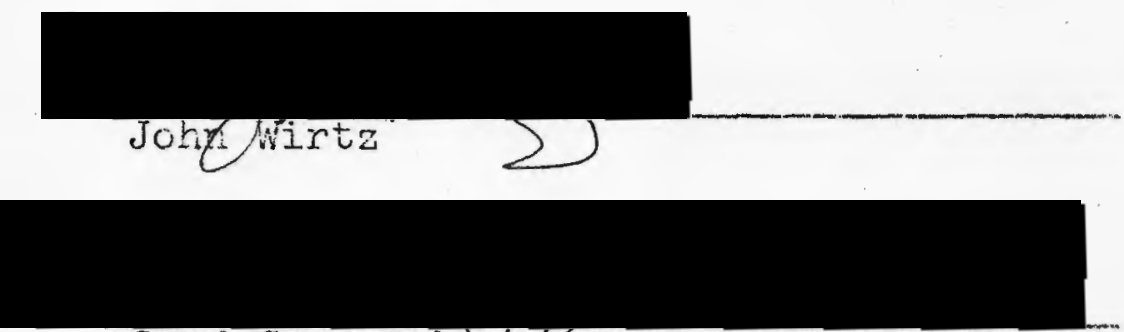

Cord Sengstakd/

APPRCVED:

Herman laylor, Heaglejology Departinent

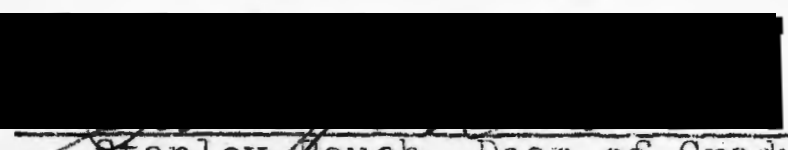

Stanley fauch, Dean of Graduate Studies and Research 


\section{ACKNOWLEDGNENTS}

The librarians at the Oregon Historical Society were most helpful in my search for old charts, and kindly allowed me to copy the material in their possession. The U. S. Corps of Engineers staff allowed me to photocopy aerial photographs in their files. Early drafts of this thesis were read and criticized by Richard Forbes, John Wirtz, Robert Tinnin, Robert Gresbrink, and Gayle Kirk. I thank my wife Gayle for her encouragement, assistance in the field, and patience during the preparation of this paper. 
TABLE OF CONTENTS

PAGE

ACKNOWLEDGMENTS ........... . . iii

LIST OF TABLES ........... . . . V v

LIST OF FIGURES . . . . . . . . . . . vii

INTRODUCTION . . . . . . . . . . . I I

METHODS ............... . 4

RESULTS

Description of the Study Site . . 9

The River

The Islands

Morphology of Sorex vagrans .... 28

DISCUSSION •. . . . . . . . . 31

CONCLUSIONS •. . . . . . . . 45

IITERATURE CITED . . . . . . . . 46

APFENDIX ............. 50 


\section{IIST OF TABIES}

TABLE

PAGE

I Percent of Individual Trap-Sites where

Common Woody Plants Occur . . . . 26

II Ratio of the Calculated Value to the

Table Value of "t" $(P<.01)$ for

First-Year Shrews . . . . . . .

III Morphometry of First-Year Shrews from

the Oregon Shore of the Columbia

River Near McGuire Island . . . . 51

IV Morphometry of First-Year Shrews from

McGuire Island . . . . . . . .

$\checkmark$ Morphometry of First-Year Shrews from

Government Island ... . . . . .

VI Morphometry of First-Year Shrews from

Upper Sand Island . . . . . .

VII Morphometry of First-Year Shrews from

Lady Island . . . . . . . .

VIII Morphometry of First-Year Shrews from

the Washington Shore of the

Columbia River near Lady Island . .

IX Morphometry of Second-Year Shrews from

the Oregon Shore of the Columbia

River near McGuire Island . . . . 
X Morphometry of Second-Year Shrews from McGuire Island . . . . . . 58

XI Morphometry of Second-Year Shrews from

Government Island....... 59

XII Morphometry of Second-Year Shrews from

Upper Sand Island . . . . . . 60

XIII Morphometry of Second-Year Shrews from

Lady Island ........ 61 


\section{LIST OF FIGURES}

1 Map of the study site, based on a recent navigation chart (U. S. Department of Commerce, 1975c) . . . . . •

2 From Government Island near its upper end, looking southward toward the Oregon shore (background) with the upper end of McGuire Island visible at the upper right. Sand bars visible here form a connection between McGuire and Government Islands at mean lower low water ............

3 U. S. Corps of Engineers aerial photograph showing the distribution of vegetation, the location of sandbars, and the relative positions of the Oregon shore (extreme bottom), McGuire Island (near bottom), Government Island (middle), Upper Sand Island (upper right), and the Washington shore (extreme upper right) ............. 
4 U. S. Corps of Engineers zerial photograph showing the distribution of vegetation, the relative positions of the Oregon shore (bottom), Lady Island (middle), and the Washington shore (top), and the narrow Camas Slough separating Lady Island from the Washington shore 15

5 From Lady Island near its lower end, looking north toward the Washington shore, showing the vegetation on the Washington shore and the sheltered nature of Camas Slough . . . . 16

6 From the Washington shore (foreground), looking across the upper end of Camas Slough toward the upper end of Lady Island, showing the narrow separation between Lady Island and the Washington shore and the moderate current in Camas Slough . . . . . . . 17

7. From the Washington shore (foreground), looking toward the City of Camas (background) with Lady Island on the left and the mouth of the Washougal River to the right, showing the narrow separation between Lady Island and the Washington shore and the gravel bars 
located at the confluence of

Camas Slough and the Washougal

River ........... 18

8 From the Columbia River between

Government Island and the lower

end of McGuire Island, looking north

toward Government Island and showing

the vegetation typical of the islands

and the somewhat sheltered nature of

the reach ............ 19

9 From the Columbia River between Upper

Sand Island and the Washington shore, looking eastward (upstream) into Camas

Slough between the Washington shore

(left) and Lady Island (right), showing

the width of the slough and the greater

exposure of the reach between Upper

Sand Island and the: Washington shore

compared to the slough ....... 20

10 From the Columbia River mair channel north

of Government Island, looking eastward

(upstream) toward the Washington shore

(extreme left), Lady Island (left),

Upper Sand Island (center), Government

Island (right), and the Oregon shore

(extreme background). The low profile 
of the islands and the exposed nature of the intervening reaches would make swimming difficult for shrews ... . . . . . . . .

Il From the middle of the Columbia River looking westward (downstream) toward McGuire Island (left), Government Island (center), and Upper Sand Island (right), showing the low profile of the islands and the exposed nature of the river at mid-channel ..........

12 The interior of Government Island near its upper end, showing the forest floor and vegetation... . . 24

13 Recorded changes in the study site. Based on a chart by Broughton in 1792, a chart by Lewis and Clark in 1806, and on topographic maps by the U.S. Coast and Geodetic Survey (1904, 1921, 1937) and the U. S. Geological Survey (1954) •. •. . . . .

14 Separation of first- and second-year Sorex vagrans on the basis of tooth wear. Because their teeth are more worn, the second-year animals are clumped at the 
lower left in each case. Firstyear animals are clumped at the upper right. . . . . . . . .

15 External dimensions of first-year shrews

from islands in the Columbia River and adjacent mainland shores. Short horizontal lines indicate the means, vertical solid bars the ranges, and vertical open bars the 99 percent confidence intervals for the means. .

16 Longitudinal cranial dimensions of firstyear shrews from islands in the Columbia River and adjacent mainland shores. Short horizontal lines indicate the means, vertical solid bars the ranges, and vertical open bars the 99 percent confidence intervals for the means . . . . . . . 34

17 Cranial breadth and depth in first-year shrews from islands in the Columbia River and adjacent mainland shores. Short horizontal lines indicate the means, vertical solid bars the ranges, and vertical open bars the 99 percent confidence intervals for the means.. 
18 Dental dimensions of first-year shrews from islands in the Columbia River and adjacent mainland shores. Short horizontal lines indicate the means, vertical solid bars the ranges, and vertical open bars the 99 percent confidence intervals for the means . . 36

19 Pelage reflectance in first-year shrews from islands in the Columbia River and adjacent mainland shores. Short horizontal lines indicate the means, vertical solid bars the ranges, and vertical open bars the 99 percent confidence intervals for the means . . 37

20 Body weight, cranial weight, and maxillary tooth row length in first-year shrews from islands in the Columbia River and adjacent mainland shores. Short horizontal lines indicate the means, vertical solid bars the ranges, and vertical open bars the 99 percent confidence interval for the means. . 38

21 Average taxonomic distances between firstyear shrews from islands in the Columbia River and adjacent mainland shores. Calculations are based on standardized character means . . . 39 


\section{INTRODUCTION}

A drastic reduction in gene flow between populations is usually indicated by morphological discontinuity (Mayr, 1966). To determine the role of the Columbia River as a barrier to gene flow in the vagrant shrew, Sorex vagrans vagrans Baird, I investigated morphological variation in shrews from populations on several islands and the adjacent mainland shores.

I selected Sorex vagrans for study because Kirk (1976) had found it on all river islands she studied. There are 42 islands or island groups (a single island at mean lower low water, but divided into more than one at high water) in the Columbia River between its mouth and Bonneville Dam which remain exposed at mean high water and which are still separated by water from one another and from the mainland at mean lower low water (based on U. S. Department of Commerce, 1974, 1975a, 1975b, 1975c). I selected two of these islands plus two islands of an island group for study. All are located near one another, but are separated from each other " and from the mainland shores by reaches with different widths, depths, and wind exposures. They are described later.

Fox (1948) studied morphological variation in the deer mouse, Peromyscus maniculatus, along the Columbia 
River from the vicinity of the Wallowa Mountains to the Pacific Ocean. He concluded that the Columbia River is a complete barrier at its western end, but that from Cowlitz County, Washington, eas.tward it seems to permit a small amount of migration across it. Fox's only island sample was five mice from Puget Island. I found no other study elucidating the role of the Columbia River as a barrier to gene flow in small mammals. Gordon (1966) observed that the Columbia River is not as much of a barrier for mammalian species or subspecies as might be expected, but speculated that careful study might reveal more subspecific differentiation than was previously recognized. He also stated that there is no better opportunity in North America for the study of the barrier influence of a river than that provided by the Snake-Columbia system.

Grinnell and Hill (1936) found that the Colorado River serves as a barrier between subspecies of pocket gophers, although Goldman (1931) had earlier concluded that similarities between gophers on both sides of the lower Colorado River were due to channel shifts which transferred large areas from one side to the other. Goldman (1937) stated that the Colorado River has boen an effective barrier to "numerous" non-aquatic and non-volant species and subspecies of mammals. Kelson (1951) concluded that the effectiveness of the Colorado River and the Green River as barriers to rodents becomes progressively less upstream. 
Shrews have been reported from marine islands (Hall, 1938; Cowan, 1941; Manville, 1942, 1964; Cameron, 1958), lake islands (Dice, 1925; Manville, 1950), and river islands (Pruitt, 1951; Kirk, 19.76). Early studies of speciation in shrews from islands off the west coast of North America have been summarized by Findley (1955) and Hall and Kelson (1959). The latter recognize at least five subspecies unique to islands off the coasts of British Columbia and Alaska.

In summary, the work of others suggests:

1) shrews are established on islands in oceans, salt water bays, freshwater lakes, and rivers, and probably occur on most islands in the lower Columbia River;

2) other rivers have been observed to restrict gene flow in various small mammals, and the Columbia River has been found to restrict gene flow in Peromyscus maniculatus, so the Columbia River may restrict gene flow in Sorex vagrans;

3) island populations of shrews have differentiated off the coasts of British Columbia and Alaska, and, if the Columbia River does restrict gene flow, they may have differentiated on islands there as well. 


\section{METHODS}

McGuire Island, Government Island, Upper Sand Island, and Lady Island were chosen for study. McGuire and Government Islands are part of a four-island group. Upper Sand Island is unnamed on navigation charts (U. S. Department of Commerce, 1975c), but is called "Sand Island" on topographic quadrangle maps (U. S. Geological Survey, 1961). To avoid possible confusion with an island located about six kilometers downstream and called Sand Island on both navigation charts and topographic maps, I have called the island in this study Upper Sand Island.

The islands are located between the cities of Camas, Clark County, Washington, and Portland, Multnomah County, Oregon, in the vicinity of $45^{\circ} 34^{\prime}$ north latitude and $122^{\circ}$ $27^{\circ}$ west longitude. Descriptive information for these islands was obtained by first-hand observation, by examination of recent navigation charts and topographic maps, by examination of early charts and maps in the archives of the Oregon Historical Society, from various historical, geological, and climatological literature, and from aerial photographs by the U. S. Corps of Engineers. This information is detailed and is important for evaluation of the shrew morphological data, so. I have included it in the Results section. 
Unbaited pitfall traps were made by embedding number 10 cans $(15.5 \mathrm{~cm}$ in diameter by $17 \mathrm{~cm}$ deep) upright in the soil so their open ends were flush with or slightly below the ground surface. Early experience revealed these traps to be effective for shrews, but the willingness of shrews to eat one another (Jackson, 1928) resulted in damage to or destruction of about 40 percent of those taken. This problem was solved by putting water $(2-3 \mathrm{~cm}$ deep) in the bottom of each can; the shrews died before they could damage one another. All shrews for this study were taken in this way.

Traps were set in rough lines to facilitate checking and retrieval. Each trap was set next to a log, stump, or other potential shrew harborage. Traps were left one to three nights and were checked early each morning. Trap lines of ten traps each were placed at three sites on the Oregon shore opposite the upper end of McGuire Island, at four sites on McGuire Island, at four sites near the upper end of Government Island opposite McGuire Island, at two sites on Upper Sand Island, near the lower end of Lady Island, and on the Washington shore opposite the lower end of Lady Island. Trapping on the islands and Washington shore was accomplished between 3 and 18 October 1975, and on the Oregon shore on 22-23 October 1976. A total of 230 trap nights yielded the 115 shrews used.

Shrews were refrigerated on ice or frozen on dry ice 
in the field and later transferred to a freezer for storage. All were made into standard mammalogical study skins. Fresh skulls were submerged in boiling water for a few minutes, then hand-cleaned and dried without bleaching.

External body dimensions (total length, tail length, hind foot length) of freshly thawed specimens were measured to the rearest millimeter with a steel ruler following the methods outlined by Hall (1962). After the fur was dried with cornmeal, body weight was measured to the nearest .0I gram on a Cent-0-Gram triple beam balance. When study skins had dried, reflectances of midventral and middorsal fur were measured using a calibrated variable resistance photocell-ohmmeter combination, in conjunction with a 40-power microscope, an incandescent light source, and a reutral gray card (19 percent reflectance) as an external standard. The length of the longest hair at the tail tip was determined by bending the hairs at right angles to the tail and measuring from the center (axis) of the tail to the tip of the longest hair using a 7-power hand-held optical comparator and reading to the nearest 0.1 millimeter. All cranial measurements were made to the nearest .01 millimeter with vernier calipers using the methods described by Jackson (1928) and Findley (1955), with the following exceptions and additions:

1) the overall cranial length was measured from the anterior-most portion of the first upper incisor to the 
posterior-most projection of the occiput;

2) the condyloinfraorbital length was measured from the posterior margin of the infraorbital foramen to the posterior-most portion of the occipital condyle on the same side;

3) the occlusal aspect of the maxillary tooth row length was measured to the nearest 0.1 millimeter using a 7-power hand-held optical comparator;

4) the palatal length also was measured with the optical comparator;

5) cranial weight was measured to the nearest milligram on a double-pan analytical balance;

6) first upper incisor length was measured along a perpendicular from the line through the two posterior-most projections of the cingulum to the anterior-most point on the tooth;

7) first upper incisor height was measured along a parallel to the line through the two posterior-most projections of the cingulum, starting at the superior-most point on the tooth and running to the inferior-most projection of the cusp;

8) height of the labial aspect of the first lower molar was measured from the inferiormost portion of the cingulum to the superior-most point of the largest cusp;

9) length of the ventral aspect of the first lower incisor was measured from the posterior-most point on the 
cingulum to the anterior-most point on the cusp.

All dental measurements were made with a 50-power microscope and a calibrated ocular micrometer. A grid micrometer was used for the upper incisor measurements and a line-scale micrometer for the lower molar and incisor measurements. Dental measurements were made to the nearest .02 millimeter. 


\section{RESULTS}

\section{DESCRIPTION OF THE STUDY SITE}

The River

In the vicinity of the study site (Figure 1), the level of the Columbia River is subject to a diurnal tidal fluctuation of less than 0.6 meter (based on U. S. Department of Commerce, 1975c). This tidal influence may be overshadowed by water release schedules at Bonneville Dam. The Columbia River also undergoes seasonal fluctuations in level and is unusually regular in its highwater cycle. A single high-water period occurs each year in summer and is due primarily to snow melt at high altitudes. Storm rainfall may contribute to flooding west of the Cascade Mountains (Rantz and Riggs, 1949).

The Columbia River has frozen over at Vancouver, Washington, at least twice: during the winter of 1861-62, and in December 1919 (Pacific Northwest River Basins Commission, 1969). It probably froze over at the study site as well, because temperatures are often lower to the east (e.g. in 1861-62 the low temperature at Vancouver was $-7^{\circ} \mathrm{F}$ and at The Dalles was $-30^{\circ} \mathrm{F}$ ). Although the Columbia River has not frozen over recently, there is no reason to believe it won't in the future. The temperature regime in the 


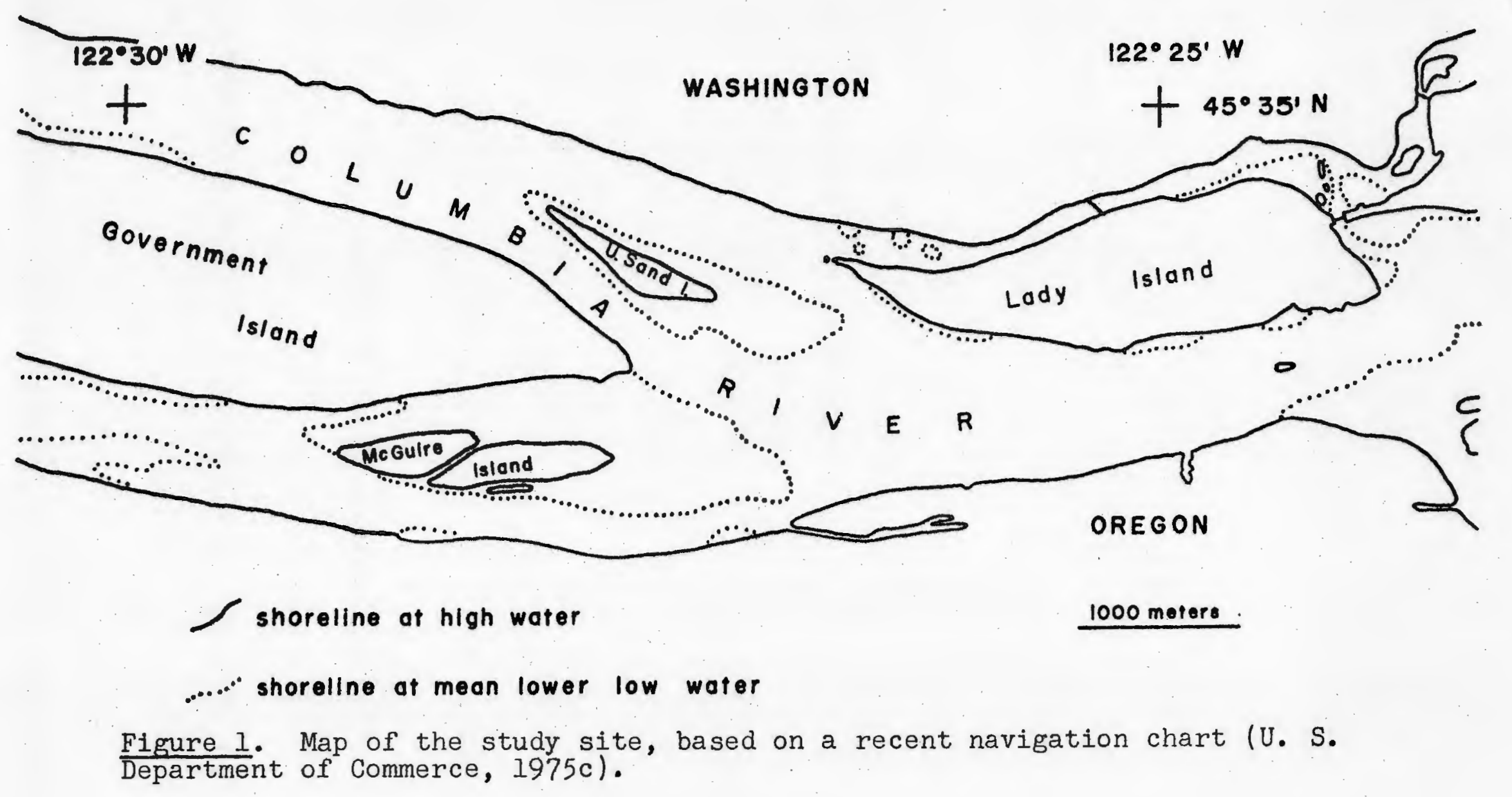


Columbia River below Bonneville Dam is still regarded as essentially the "natural" one (Columbia Basin Interagency Committee, 1966), and the period of uniformly good weather during the last few decades is thought by some climatologists to be at an end (Shapley, 1976).

\section{The Islands}

McGuire Island has an area at mean high water of about 22 hectares (based on U. S. Department of Commerce, 1975c). It is part of a four-island group which also includes Government Island. The water between the upper ends of McGuire and Government Isiands is shallow (Figure 2) and at the lowest river stages the two islands are connected by a sand bar bridge (based on U. S. Department of Commerce, 1975c). The pile dike installed about 25 years ago (Figure 2) has probably increased the deposition of sand. there. The two islands are separated from the Oregon shore by a relatively wide but shallow channel which is used by pleasure boats but not by commercial river traffic. The area of Government Island at mean high water is about 729 hectares (based on U. S. Department of Commerce, 1975c).

Upper Sand Island is separated from Government Island by the main dredged navigation channel, from the Washington shore by a wider but shallower channel used by tugs for. access to Camas Slough, and from Lady Island by a wide reach of shallow water with a narrow channel used by small 


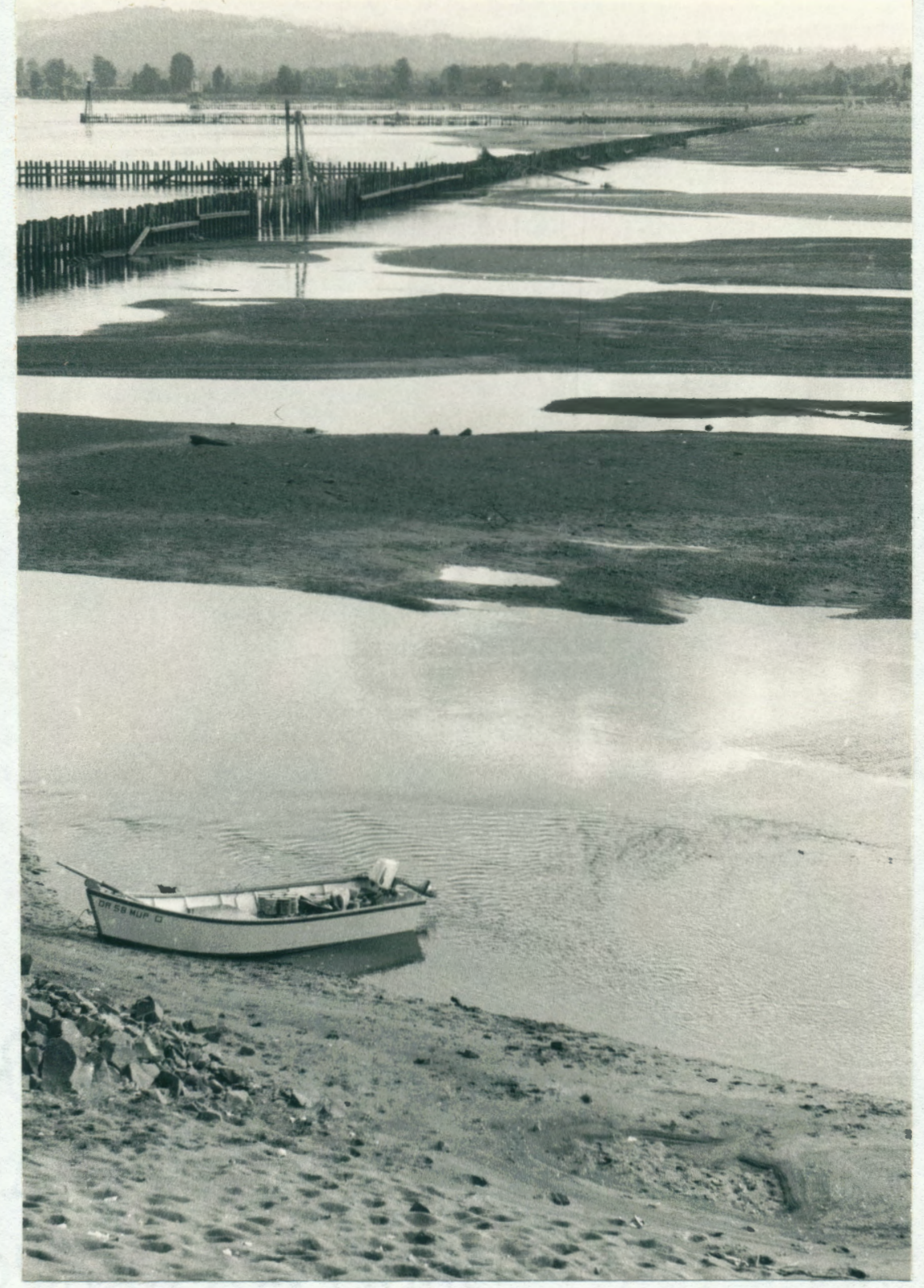

Figure 2. From Government Island near its upper end, looking southward toward the Oregon shore (background) with the upper end of McGuire Island visible at the upper right. Sand bars visible here form a connection between McGuire and Government Islands at mean lower low water. 
tugs along the Lady Island shore. The area of Upper Sand Island at mean high water is about 12 hectares (based on U. S. Department of Commerce, 1975c). The relative positions of McGuire, Qovernment, and Upper Sand Islands, and the locations of sand bars are shown in Figures 1 and 3 . Lady Island has an area at mean high water of about 175 hectares (based on U. S. Department of Commerce, 1975c). It is separated from the Oregon shore by the main navigation channel, and from the Washington shore by the narrow Camas Slough (Figures 4 and 5). Any temporary connections with the Washington shore would be most likely near the upper end of the island where the Camas Slough is particularly narrow (Figure 6) and gravel bars occur below the mouth of the Washougal River (Figure 7). Such connections probably do not occur, even at low river stages (based on U. S. Department of Commerce, 1975c). Two bridges, one of which can be seen in Figure 6, connect Lady Island to the Washington shore.

The water separating McGuire and Government Islands (Figure 8) and Lady Island and the Washington shore (Figure 5) is relatively sheltered from wave action resulting from strong winds, whereas that separating McGuire and Government Islands from the Oregon shore, Upper Sand Island from Government Island and the Washington shore (Figures 9 and 10), and Lady Island from Sand Island and the Oregon shore is more exposed. The islands exert only 


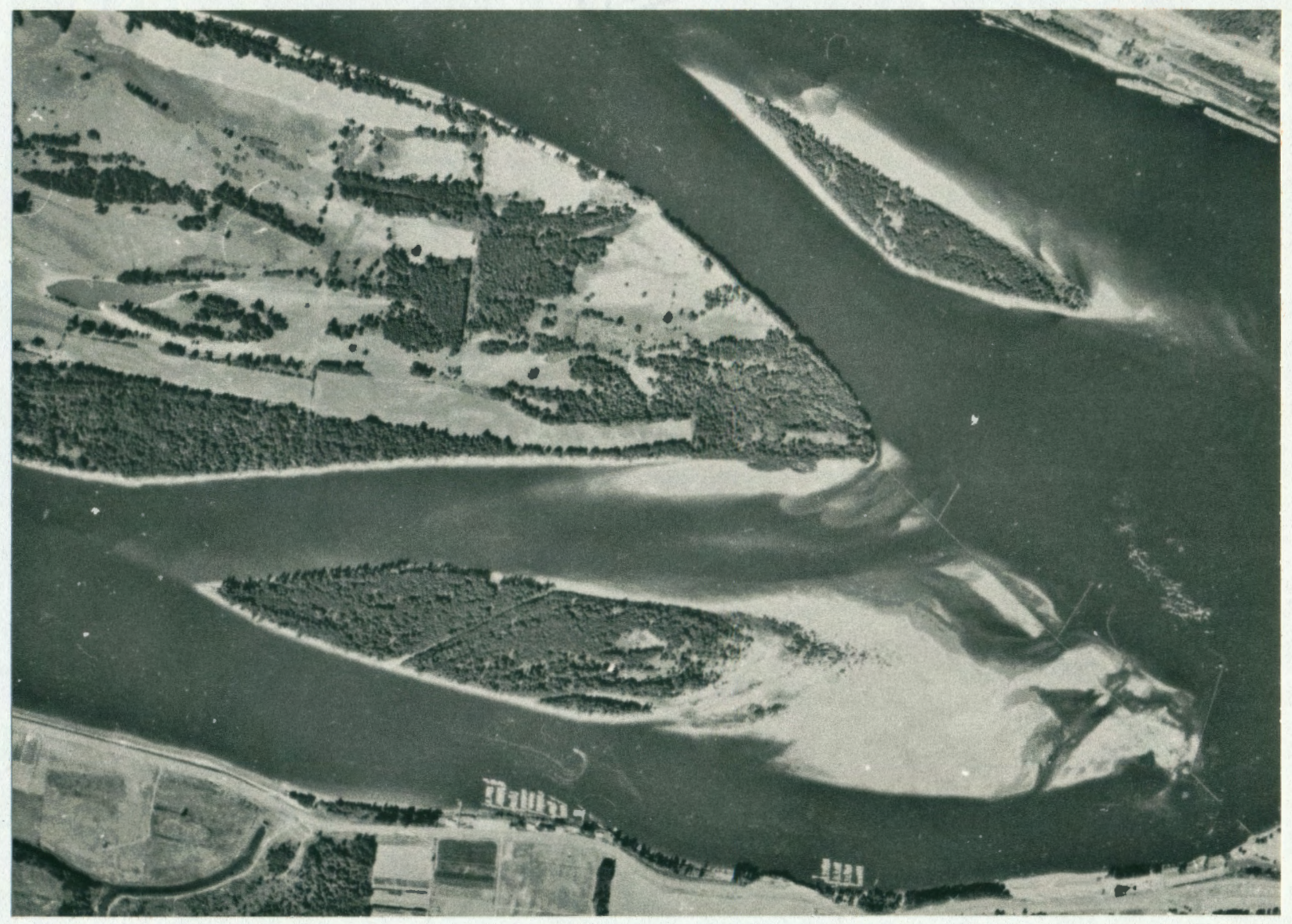

Figure 3. U. S. Corps of Engineers aerial photograph showing the distribution of vegetation, the location of sandbars, and the relative positions of the Oregon shore (extreme bottom), McGuire Island (near bottom), Government Island (middle), Upper Sand Island (upper right), and the Washington shore (extreme upper right). 


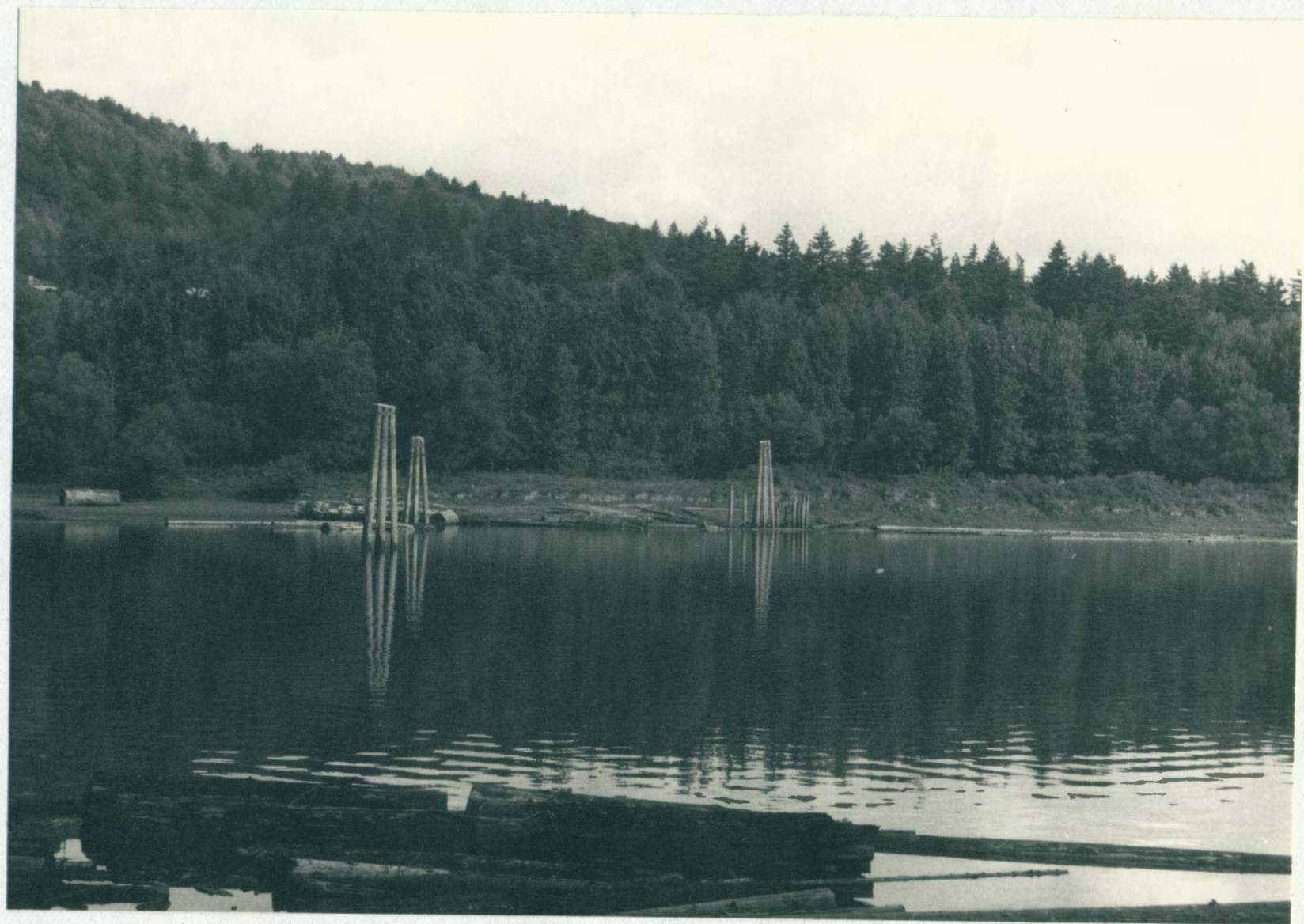

Figure 5. From Lady Island near its lower end, looking north toward the Washington shore, showing the vegetation on the Washington shore and the sheltered nature of Camas Slough. 


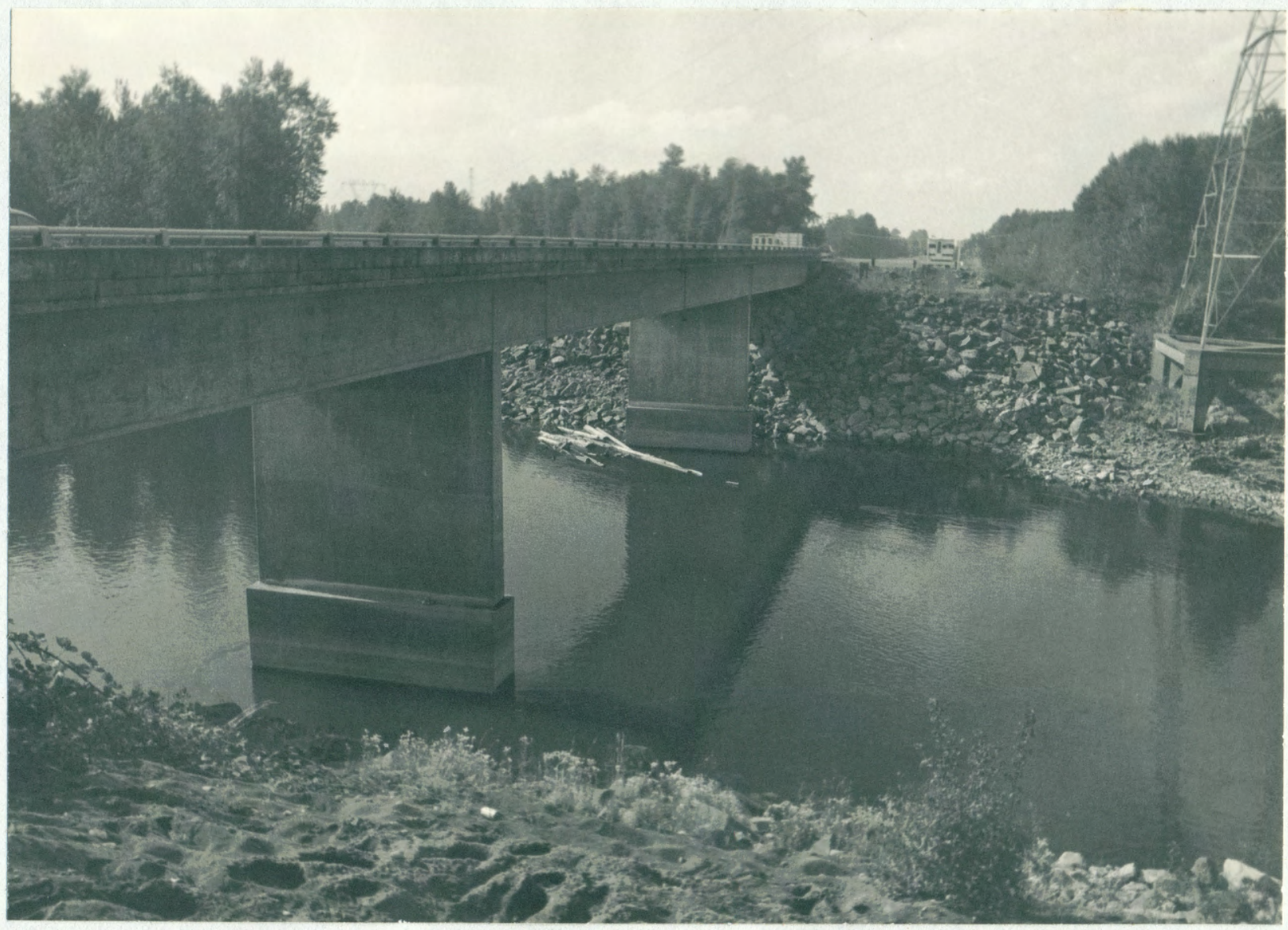

Figure 6. From the Washington shore (foreground), looking across the upper end of Camas Slough toward the upper end of Lady Island, showing the narrow separation between Lady Island and the Washington shore and the moderate current in Camas Slough. 


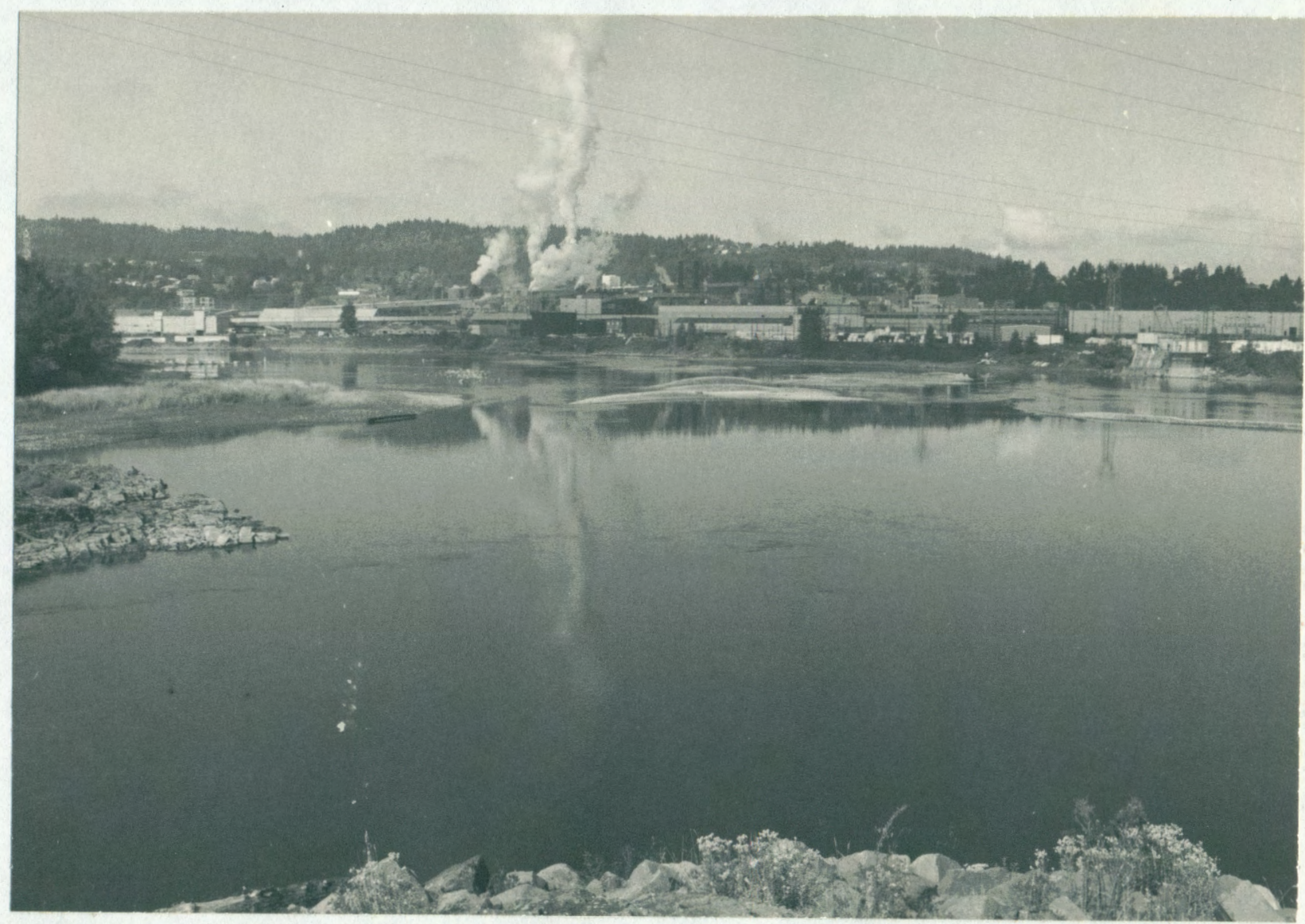

Figure 7. From the Washington shore (foreground), looking toward the City of Camas (background) with Lady Island on the left and the mouth of the Washougal River to the right, showing the narrow separation between Lady Island and the Washington shore and the gravel bars located at the confluence of Camas Slough and the Washougal River. 


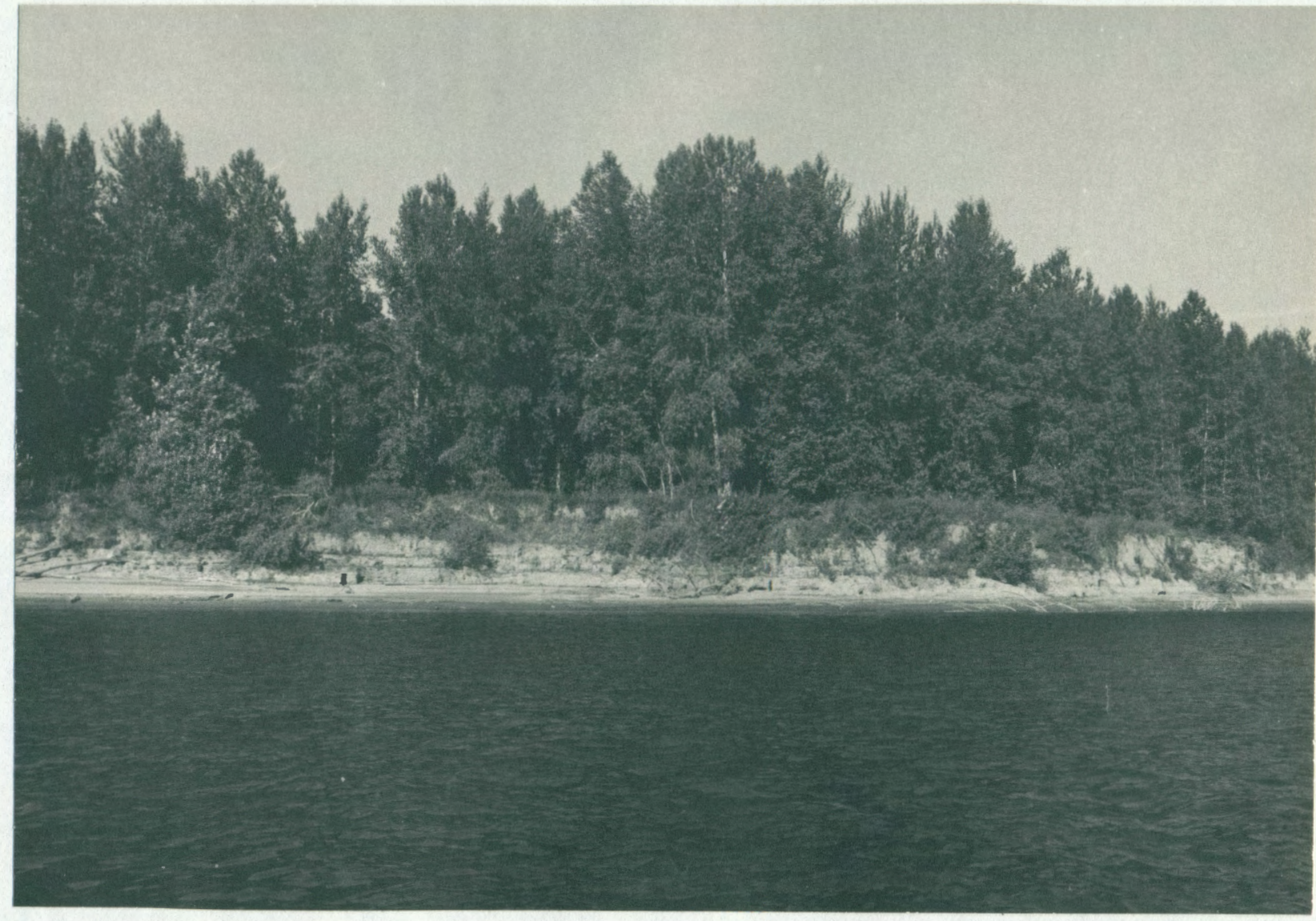

Figure 8. From the Columbia River between Government Island and the lower end of McGuire Island, looking north toward Government Island and showing the vegetation typical of the islands and the somewhat sheltered nature of the reach. 


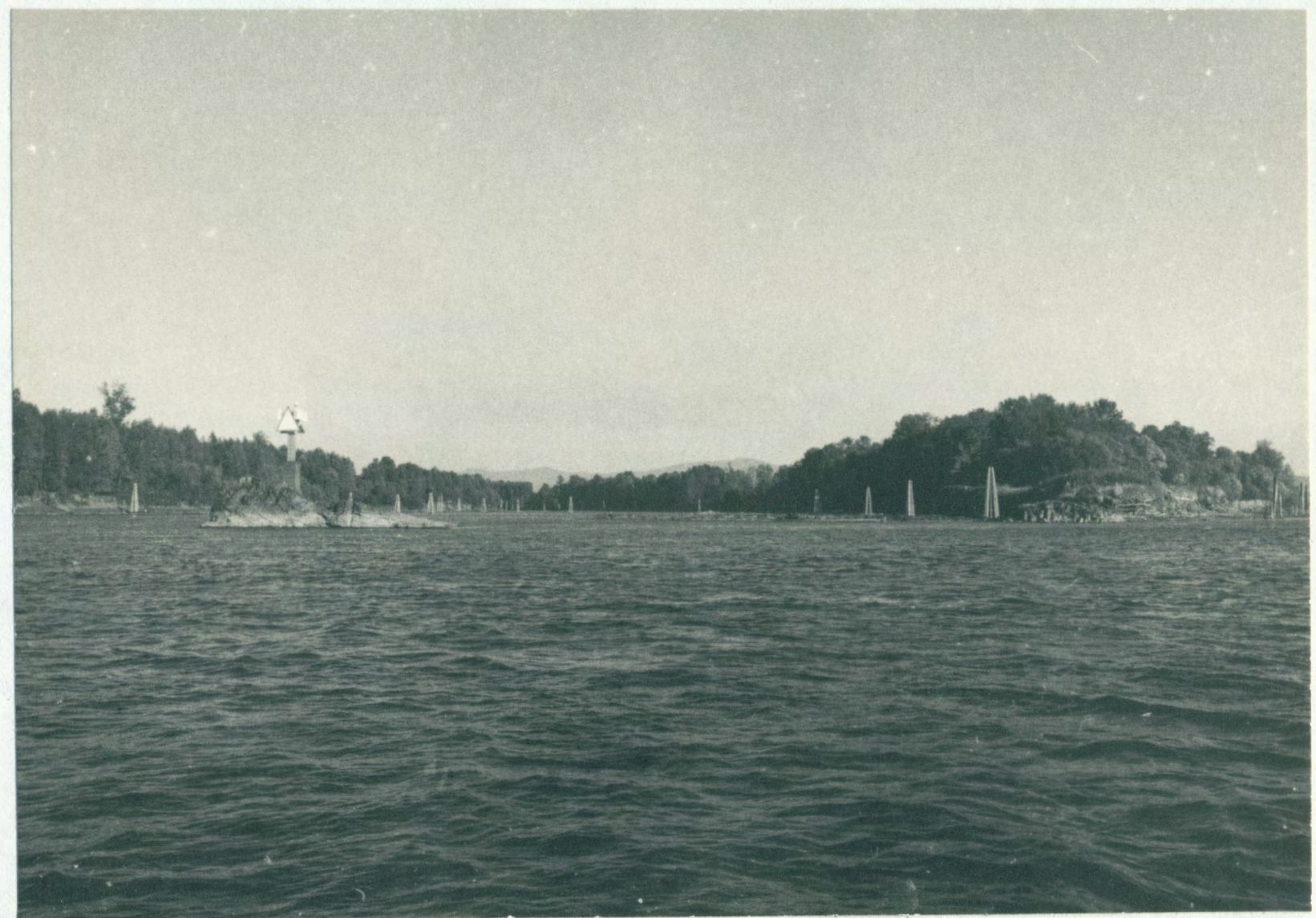

Figure 9. From the Columbia River between Upper Sand Island and the Washington shore, looking eastward (upstream) into Camas Slough between the Washington shore (left) and Lady Island (right), showing the width of the slough and the greater exposure of the reach between Upper Sand Island and the Washington shore compared to the slough. 


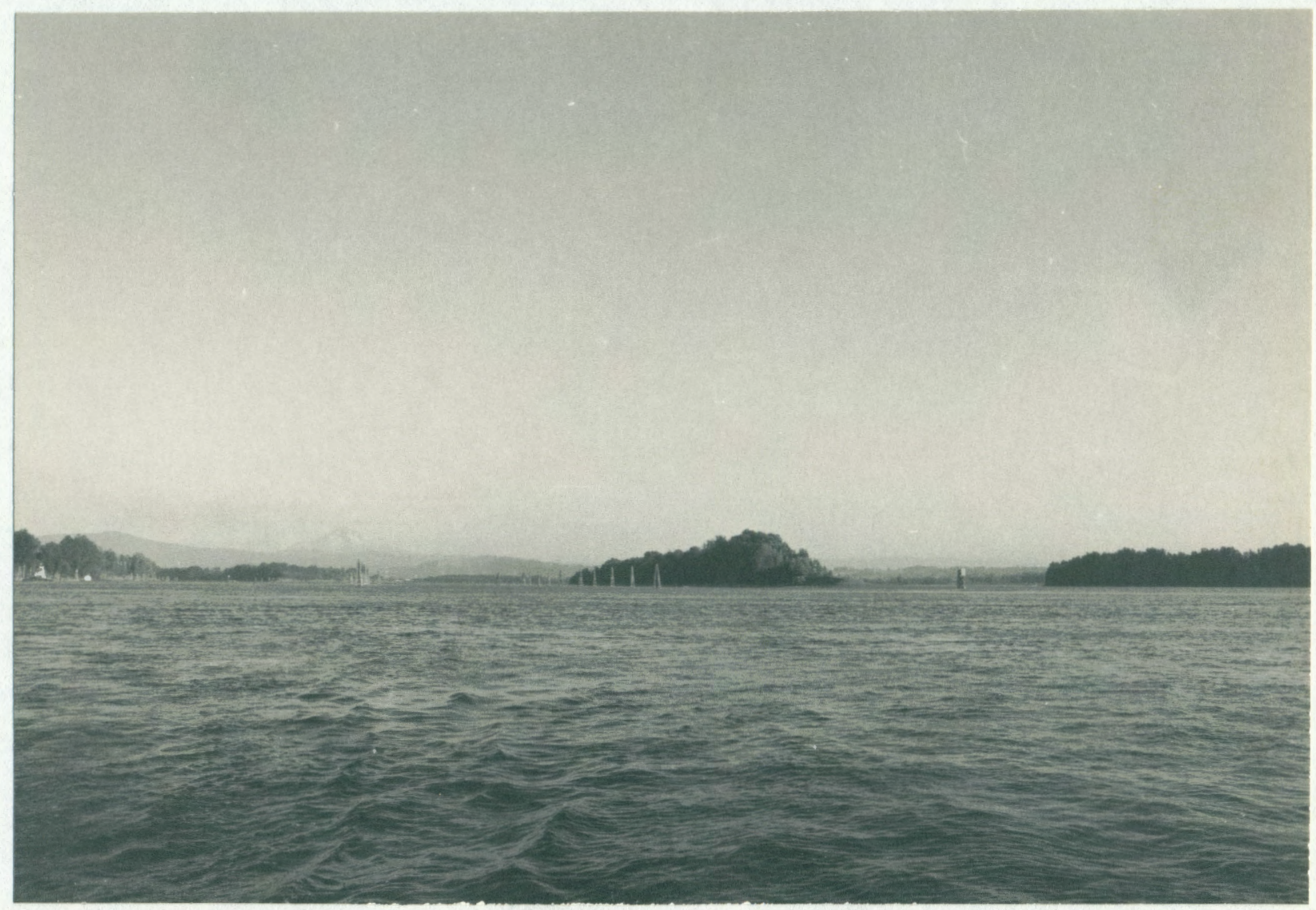

Figure 10. From the Columbia River main channel north of Government Island, looking eastward (upstream) toward the Washington shore (extreme left), Lady Island (left), Upper Sand Island (center), Government Island (right), and the Oregon shore (exteme background). The low profile of the islands and the exposed nature of the intervening reaches would make swimming difficult for shrews. 
minimal effect as windbreaks because of their low profiles (Figures 10 and 11): none exceeds about 12 meters above. sea level, or about 9 meters above the mean high water level (based on U. S. Geological Survey, 1961).

. The current in the area between McGuire and Government Islands is slow due to the sand bars restricting flow at the island heads. The current in Camas Slough is slow too. The current in other areas is faster.

The "natural" vegetation on the islands and river shores appears to be deciduous forest dominated by cottonwood (Populus trichocarpa) (Figures 8 and 12). This is the predominant vegetation on McGuire and Upper Sand Islands (Figure 3) and persists in patches on Government and Lady Islands and on the Oregon and Washington shores (Figures 3 and 4). Much of Government Island has been cleared for livestock grazing and now is pasture (Figure 3). Much of Lady Island has been cleared and now is used for holding and treating wastes from the paper plant at Camas. The Oregon shore has been modified by diking and rip-rap; much of it lacks woody vegetation. Behind the dike on the Oregon shore much of the land has been cleared for farming. The relatively steep slope down to the Washington shore has precluded the necessity for diking. Mixed coniferousdeciduous forest approaches the shore there (Figure 5), and has been cleared for agriculture in a few places. All the traps were set in forested areas; the occurrence of common 


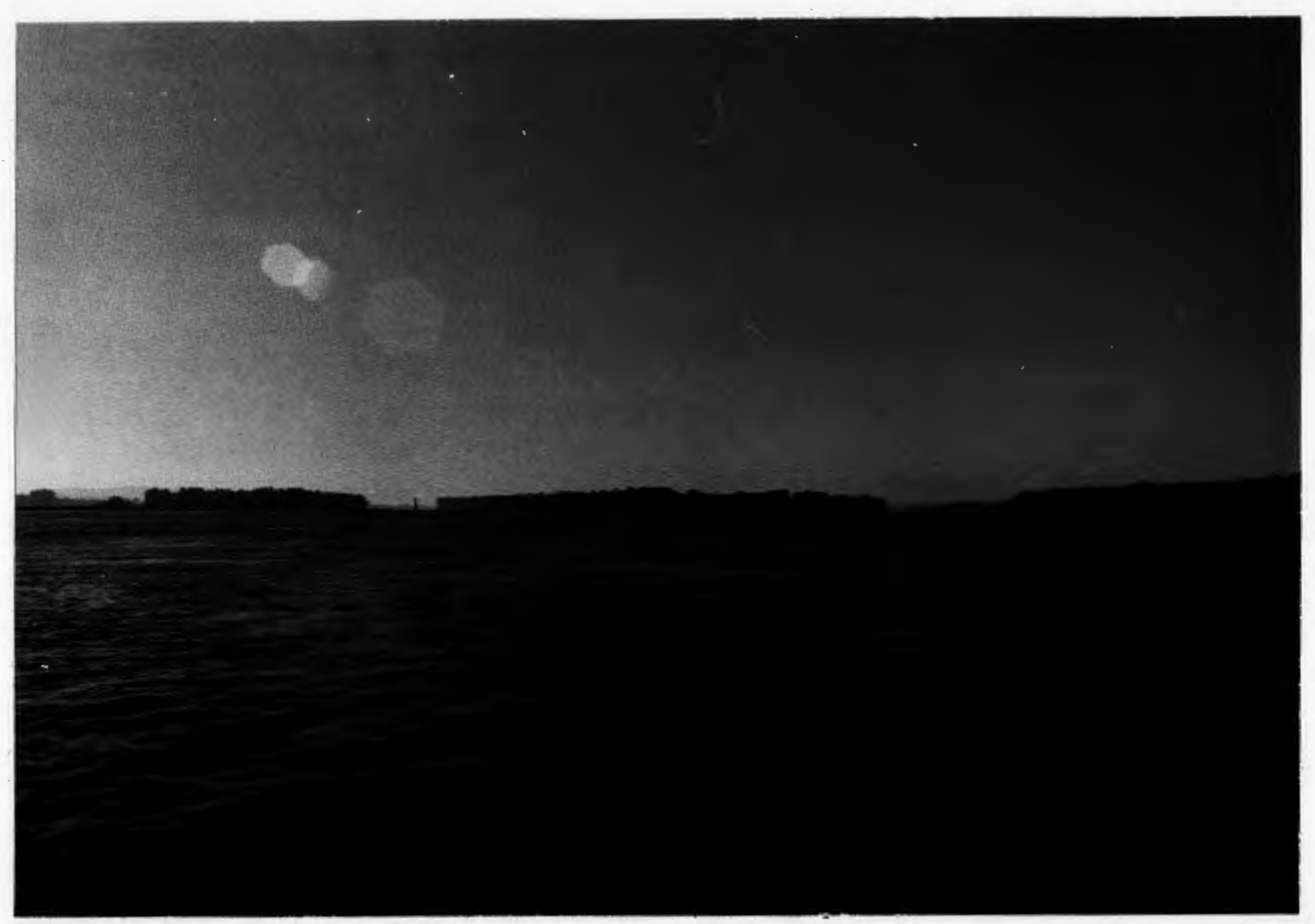

Figure 11. From the middle of the Columbia River looking westward (downstream) toward McGuire Island (left), Government Island (center), and Upper Sand Island (right), showing the low profile of the islands and the exposed nature of the river at mid-channel. 


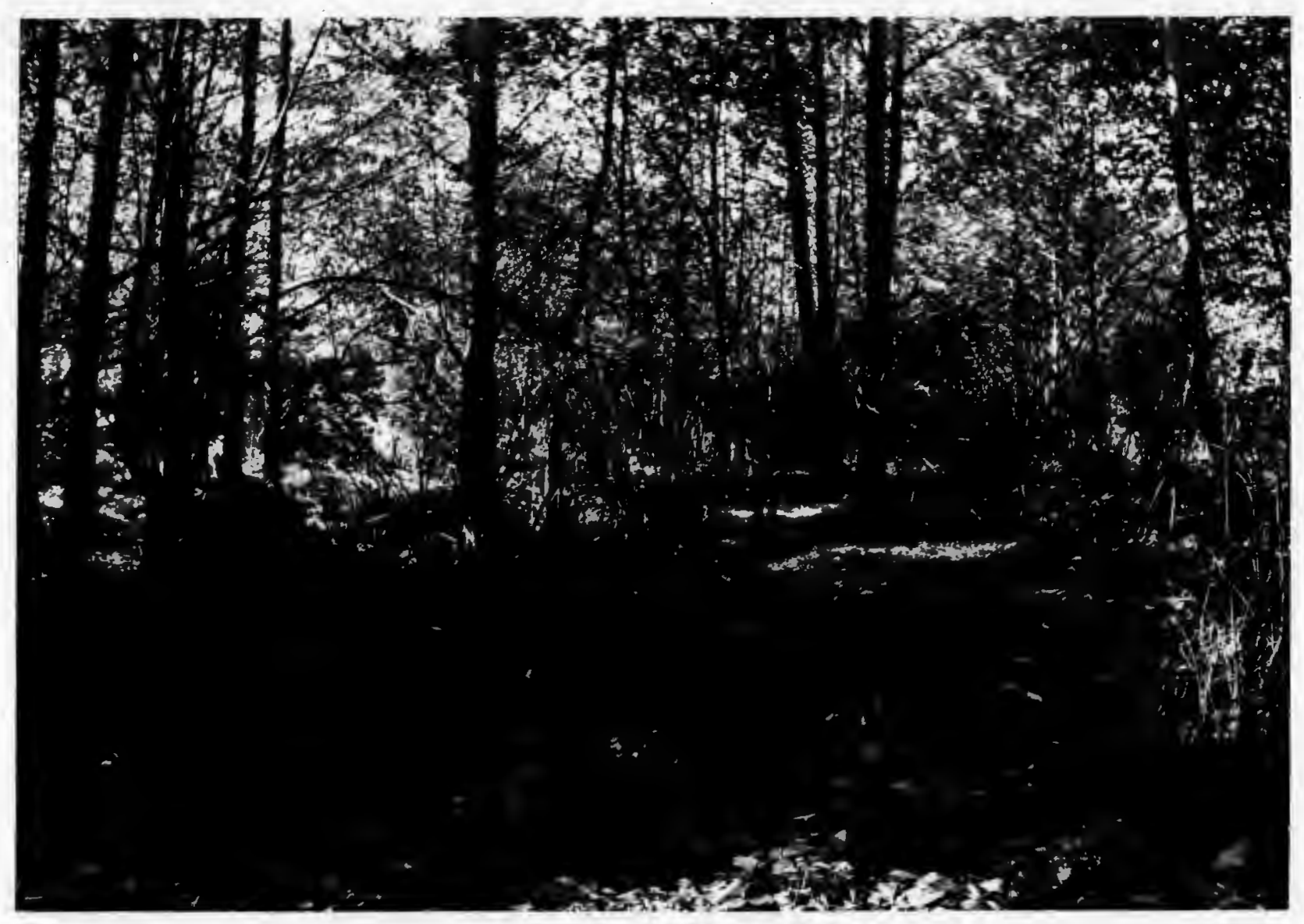

Figure 12. The interior of Government Island near its upper end, showing the forest floor and vegetation. 
woody plants at individual trap sites is summarized in Table I.

The formation of the islands is obscure. They. probably are among the Recent alluvial deposits described by Baldwin (1966). Their formation clearly must have been after the last catastrophic flood. The Missoula Flood occurred about 33,000 years B.P. and crested at about 122 meters above sea level at the west end of the Columbia Gorge, but it is not clear if that was the most recent flood (Baldwin, 1966).

The first white explorer of the lower Columbia River was Lt. Robert Broughton, a British officer under Capt. George Vancouver. He explored from the mouth up to Vancouver Point above the present town of Washougal in the autumn of 1792 (Lockley, 1928). He camped on Lady Island (which he called Johnstone's Island) and his chart shows both Lady and Government Islands, but neither McGuire nor Upper Sand Islands (Figure 13). Lewis and Clark camped on the upper part of Government Island (which they called Diamond Island) in 1805 and described Lady Island and another island below Diamond Island (which has since fused with Diamond Island to form what is now Government Island), but did not mention Upper Sand or McGuire Islands (Thwaites, 1959). It appears from maps and charts published since then that Upper Sand Island formed in place and never has been connected to other islands or to the mainland (Figure 13). 
TABLE I

PERCENT OF INDIVIDUAL TRAP-SITES WHERE COMMON WOODY PLANTS OCCUR

$\begin{array}{lccccc}\text { MCGUIRE } & \text { GOVERNMENT } & \text { UPPER SAND } & \text { LADY } & \text { WASHINGTON } & \text { OREGON } \\ \text { ISLAAND } & \text { ISLAND } & \text { ISLAND } & \text { ISLAND } & \text { SHORE } & \text { SHORE }\end{array}$

Populus

trichocarpa

$98 \quad 68$

85

90

80

90

Crataegus

douglasii

2

15

15

50

20

0

Fraxinus

latifolia

0

35

0

40

10

3

Salix

amygdaloides

12

12

15

0

20

23

Cornus occidentalis

30

17

Sambucus callicarpa

50

55

20

0

Symphoricarpus albus

2

30

0

50

10

0 


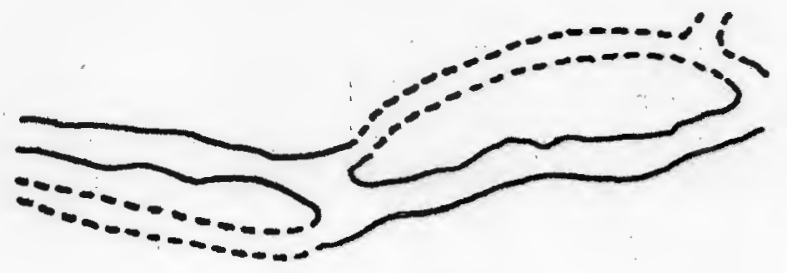

1792

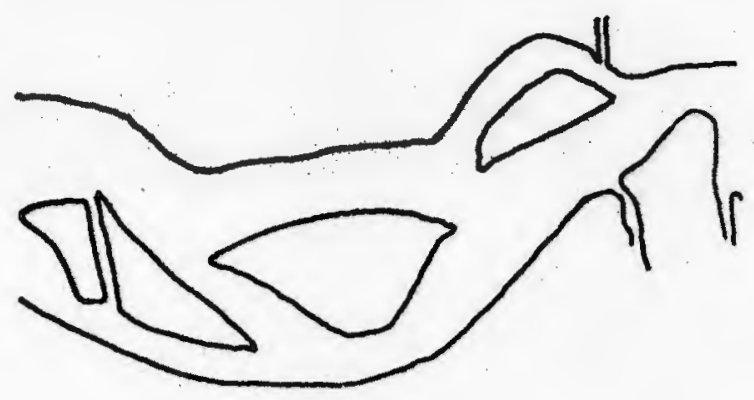

1806

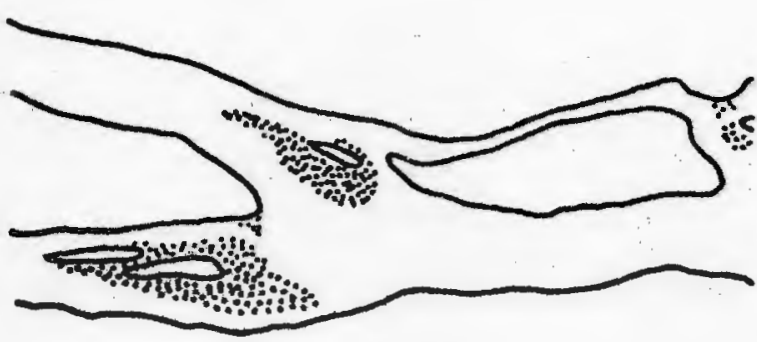

1904

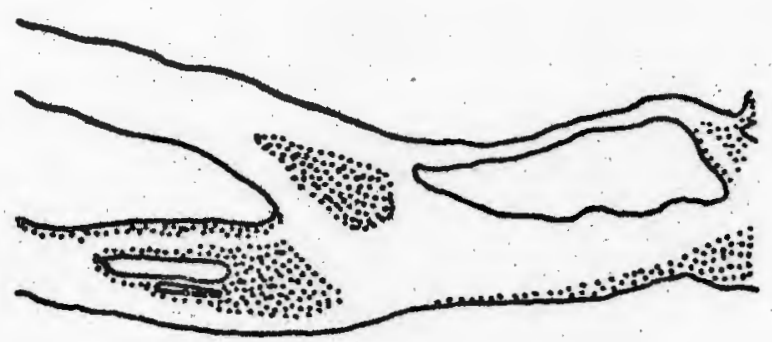

1921

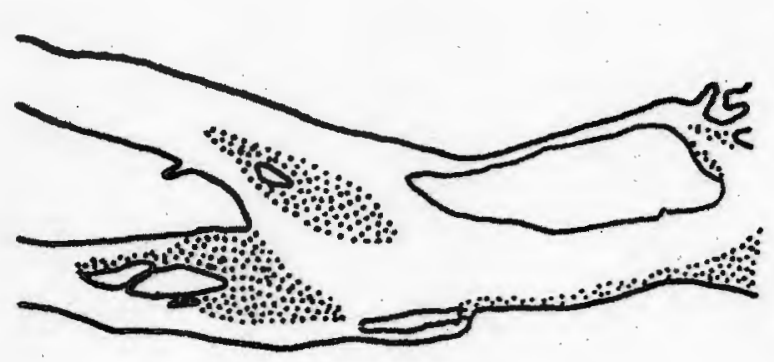

1937

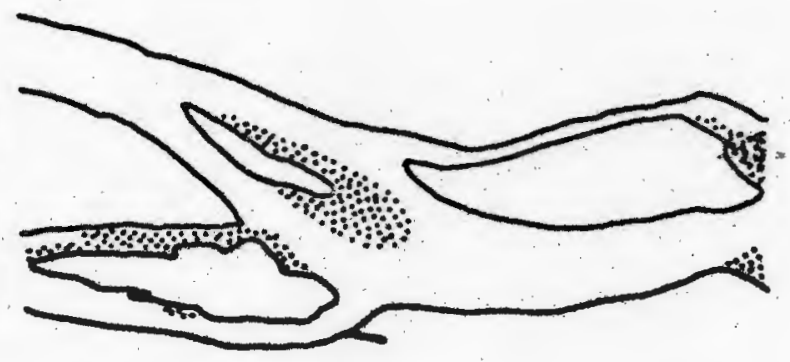

1954

\section{0 meters}

\Shoreline of high water Exposed at low water

Figure 13. Recorded changes in the study site. Based on a chart by Broughton in 1792, a chart by Lewis and Clark in 1806, and on topographic maps by the U. S. Coast and Geodetic Survey (1904, 1921, 1937) and the U. S. Geological Survey (1954). 
The origin of McGuire Island is obscure, but the most likely explanation seems to be that a new river channel formed and split McGuire off from Government Island. Two pieces of indirect evidence point to this: the shape of Lewis' and Clark's Diamond Island is approximated by combining the upper portion of Government Island with McGuire Island and the intervening water; and an elderly lady who once lived on McGuire Island told Gordon Reece that there had been fruit orchards on the upper end of McGuire Island opposite Government Island, but that they had been washed away (Gordon Reece, personal communication).

\section{MORPHOLOGY OF SOREX VAGRANS}

All the shrews collected appear to be Sorex vagrans vagrans Baird. The problems involved in studying shrew morphology have been summarized by Jackson (1928). One is that many characters change dramatically as shrews age. I attempted to reduce variability due to different ages by collecting all shrews at the same time of year. Findley (1955) was able to separate first- and second-year shrews by plotting two dental measurements, each strongly affected by tooth wear, against one another. I followed this approach and plotted first upper incisor height against first lower molar height (Figure 14). This approach graphically distinguishes first- and second-year shrews within a population, but it is ineffective when the six 

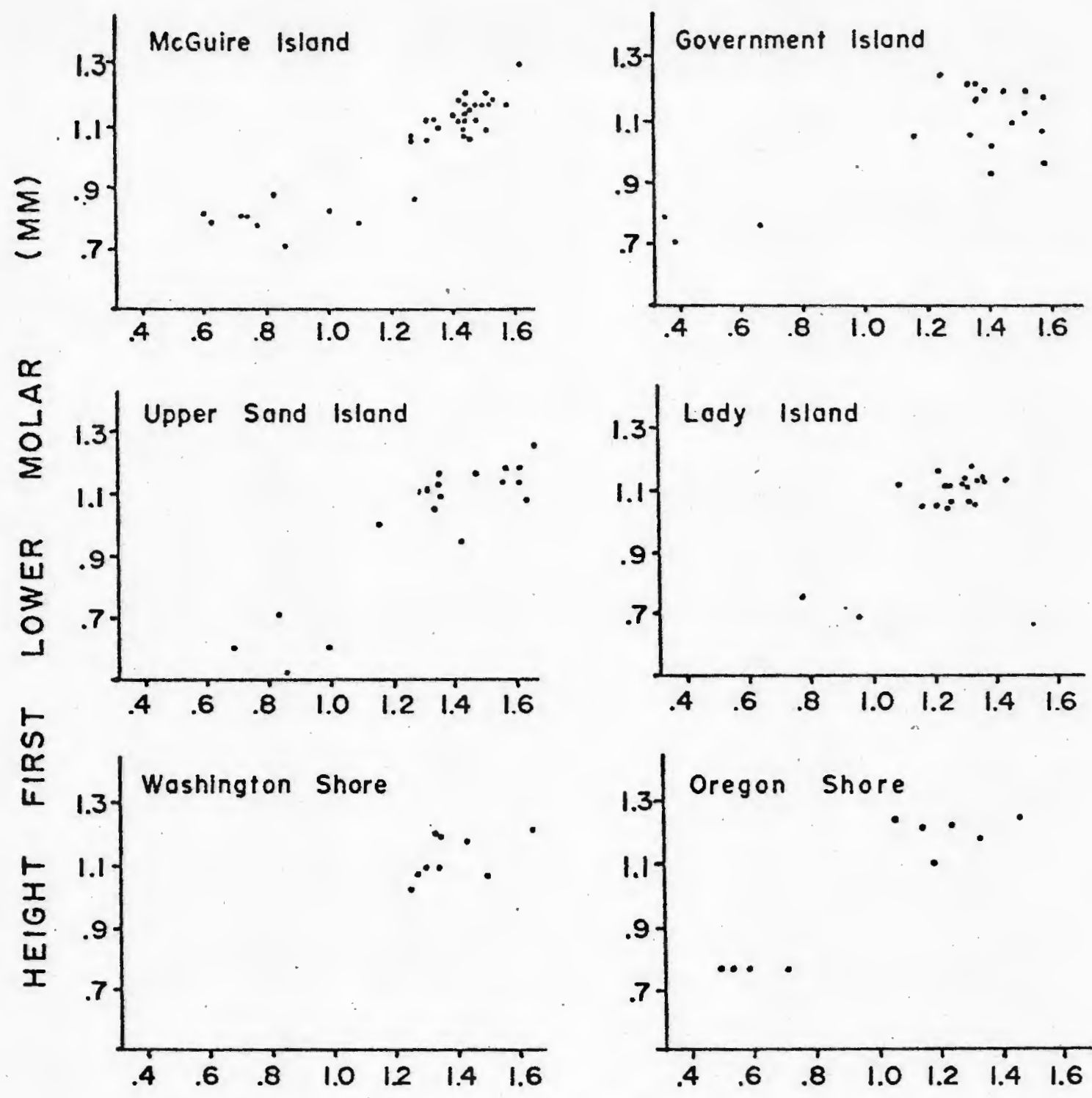

HEIGHT FIRST UPPER INCISOR (M M)

Figure 14. Separation of first- and second-year Sorex vagrans on the basis of tooth wear. Because their teeth are more worn, the second-year animals are clumped at the lower left in each case. Firstyear animals are clumped at the upper right. 
populations are combined for analysis. Morphometric data for first- and second-year shrews appear in the appendix. Jackson (1928) and Findley (1955) agreed that morphometric characters of shrews do not vary with sex, and for this reason, and because sex determination is difficult in shrews not in breeding condition, I did not attempt to detect sexual differences in morphology. Findley (1955) recommended use of first-year animals for study of pelage and measurement of cranial characters. For this reason, and because the first-year shrews alone showed less variability than the second-year shrews alone and than the first- and second-year shrews combined, I used only the data for first-year shrews in comparing the populations (Figures 15 through 20). The results of the tests for significant difference appear in Table II (t-test performed as described by Bailey, 1959, using tables in Hoel, 1960). Average taxonomic distances were calculated on the basis of standardized character means as described by Sneath and Sokal (1973); the results appear in Figure 21. 


\section{DISCUSSION}

One way of characterizing the overall difference between two populations is to count the number of characters for which the population means differ significantly (see Table II). The greater the number of significantly different character means, the more different the two populations are. This method can be extended by calculating the mean t-ratio for each pair of populations (Table II). The greater the mean t-ratio, the more different the two populations are.

Another approach is to calculate the average taxonomic distance between each pair of populations, as described by Sneath and Sokal (1973). The average taxonomic distances in Figure 21 correlate fairly well with the mean t-ratios in Table II (correlation coefficient is $.785)$.

Cautious examination of the data in Table II and Figures 15 through 21 suggests:

1) there is a tendency for shrews on McGuire, Government, and Lady Islands to be barger than those in the other populations;

2) the shrews on McGuire and Government Islands are more closely related to one another than to any of the other populations; 


\section{TABLE II}

RATIO OF THE CALCULATED VALUE TO THE TABLE VALUE OF "t" $(P<.01)^{1}$ FOR FIRST-YEAR SHREWS

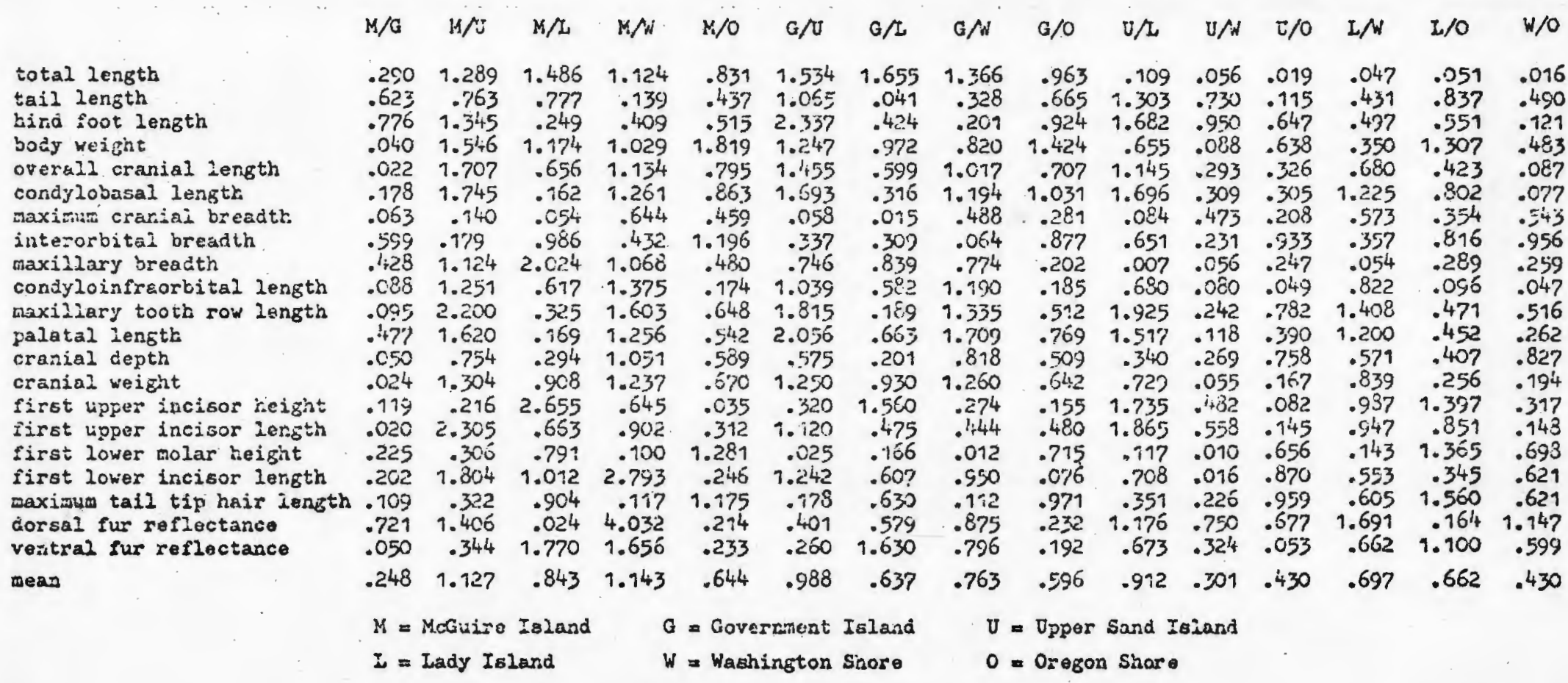

1 The character means of a pair of populations differ significantly if the ratio of the calculated value of to the table value of $t$ is greater than one. 

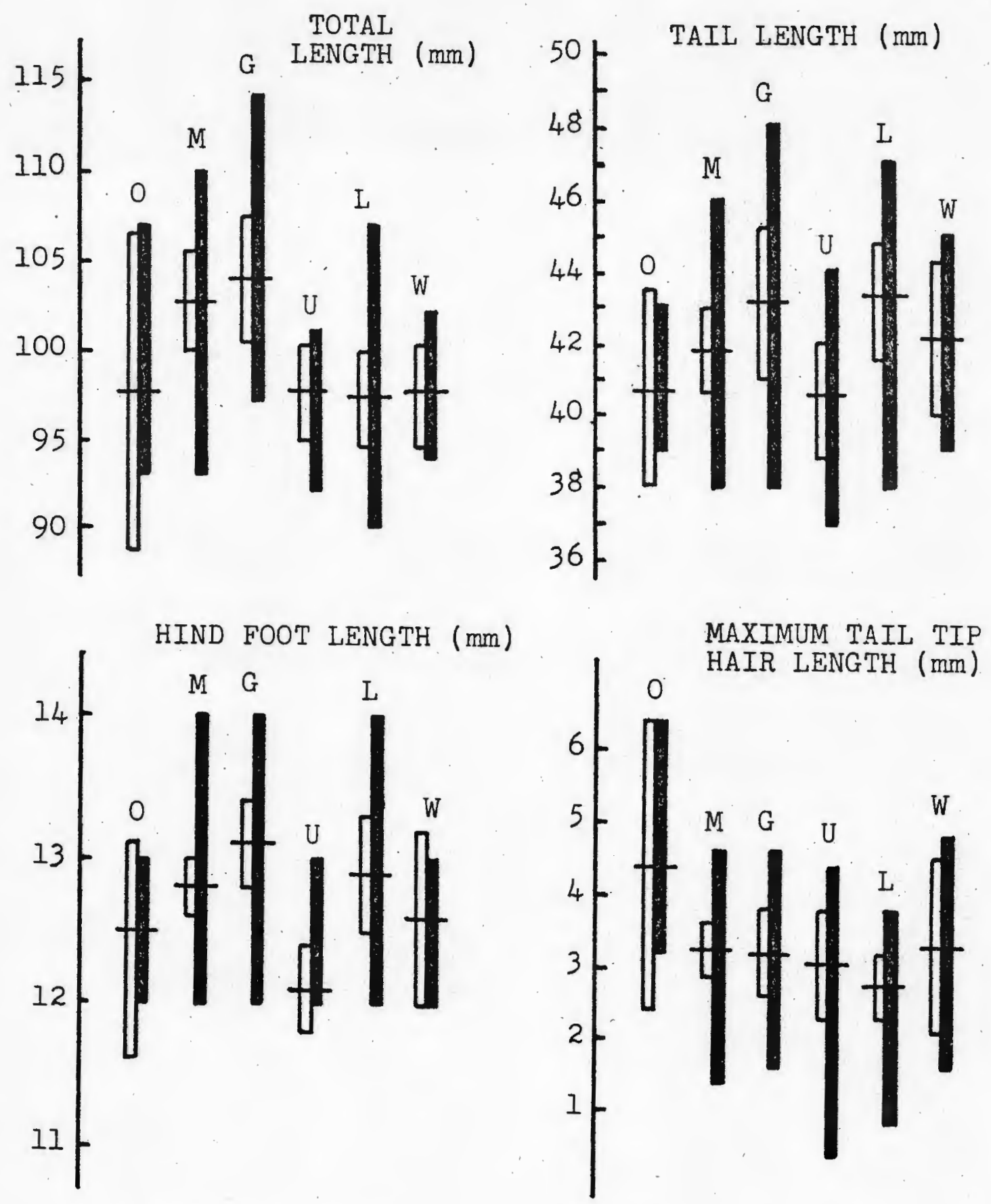

$$
\begin{aligned}
& O=\text { Oregon shore } \\
& M=\text { McGuire Island } \\
& G=\text { Government Island }
\end{aligned}
$$

$$
\begin{aligned}
& U=\text { Upper Sand Island } \\
& \mathrm{L}=\text { Lady Island } \\
& W=\text { Washington shore }
\end{aligned}
$$

Figure 15. External dimensions of first-year shrews from islands in the Columbia River and adjacent mainland shores. Short horizontal lines indicate the means, vertical solid bars the ranges, and vertical open bars the 99 percent confidence intervals for the means. 

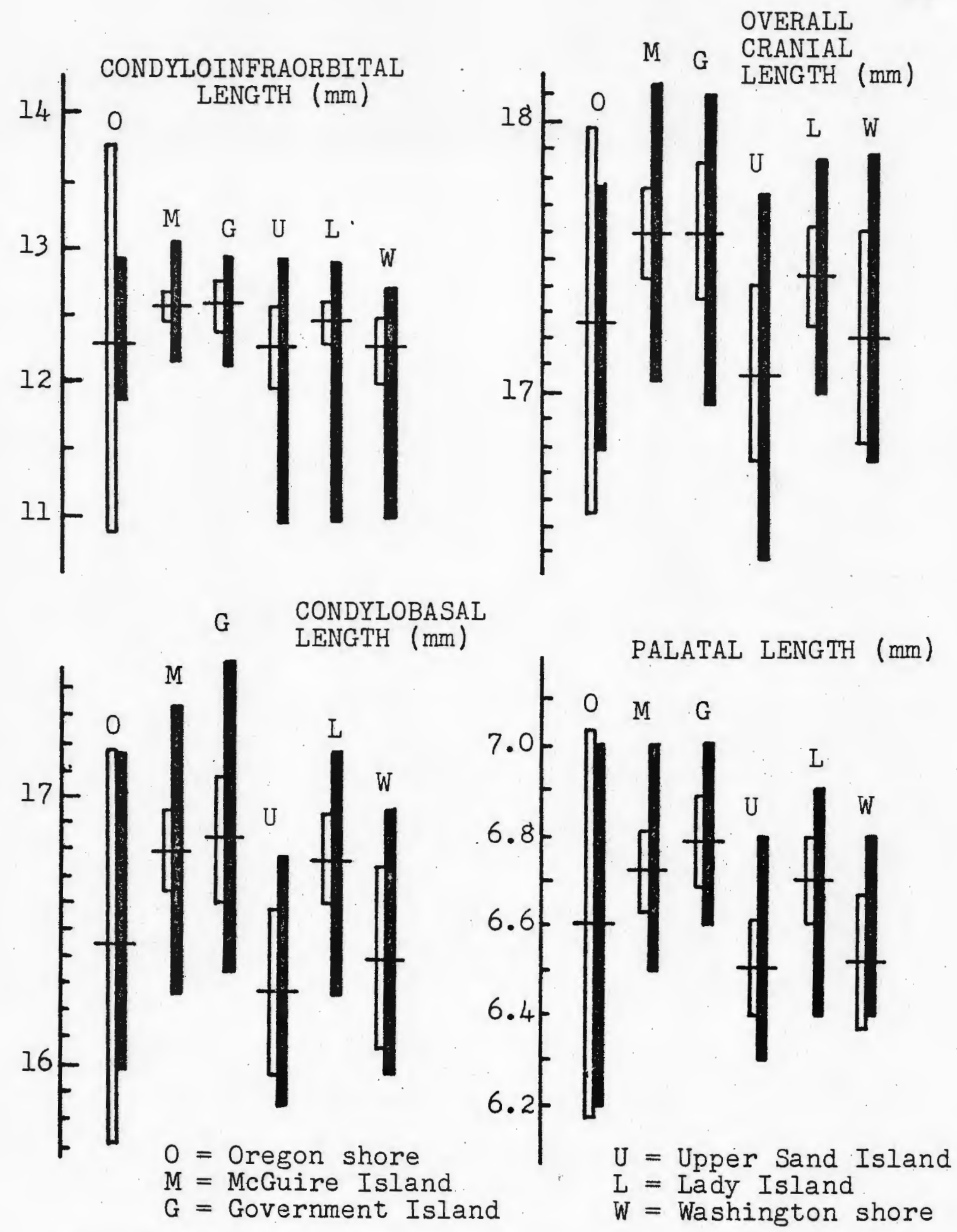

Figure 16. Longitudinal cranial dimensions of firstyear shrews from islands in the Columbia River and adjacent mainland shores. Short horizontal lines indicate the means, vertical solid bars the ranges, and vertical open bars the 99 percent confidence intervals for the means. 

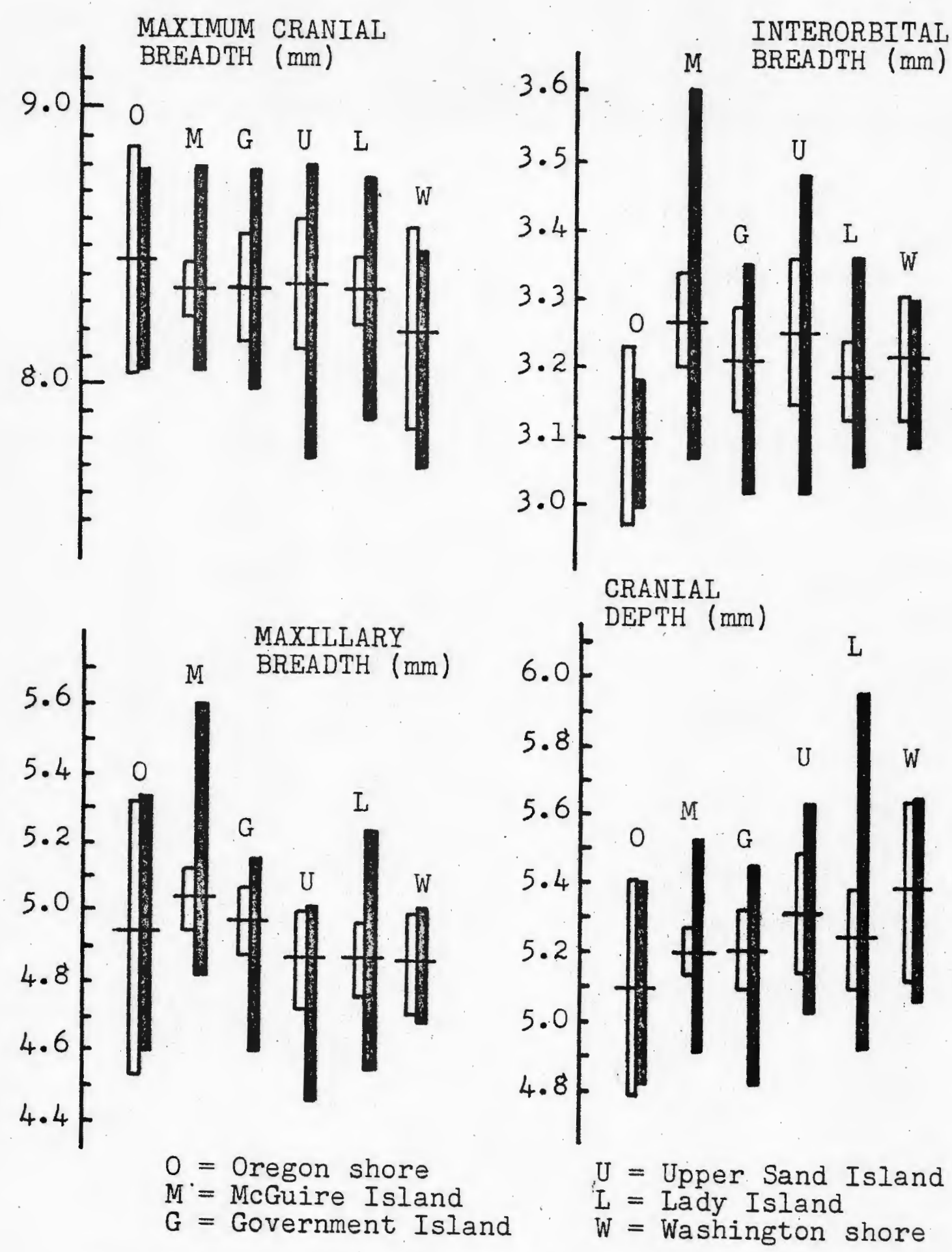

Figure 17. Cranial breadth and depth in first-year shrews from islands in the Columbia River and adjacent mainland shores. Short horizontal lines indicate the means, vertical solid bars the ranges, and vertical open bars the 99 percent confidence intervals for the means. 
FIRST UPPER INCISOR

HEIGHT (mm)

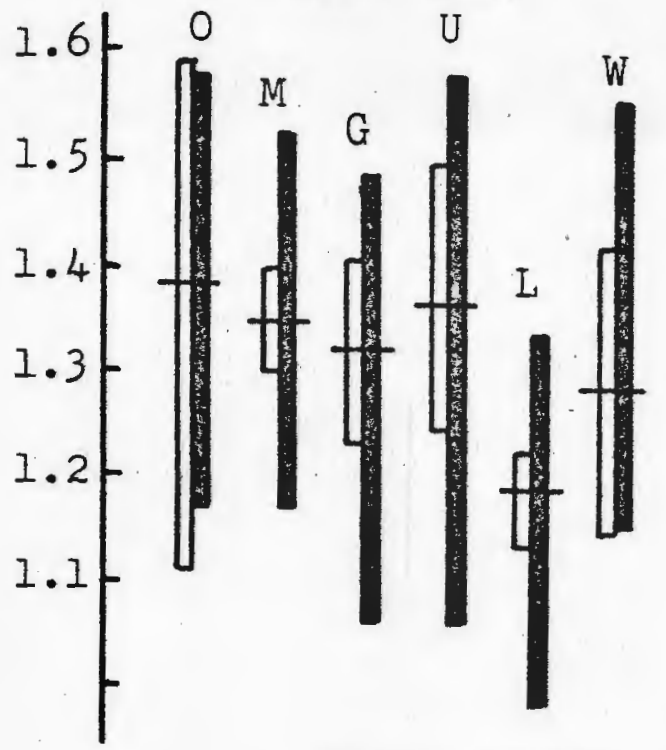

FIRST LOWER

MOLAR

$1.3[0 \cdot M$ HEIGHT $(\mathrm{mm})$

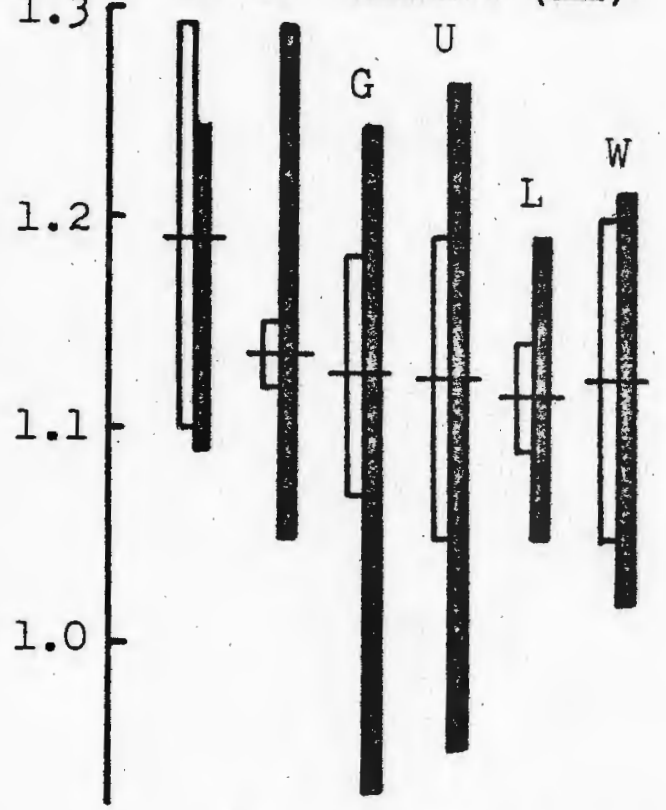

$0=$ Oregon shore

$\mathrm{M}=$ McGuire Island

$G=$ Government Island
FIRST UPPER INCISOR LENGTH (mm)

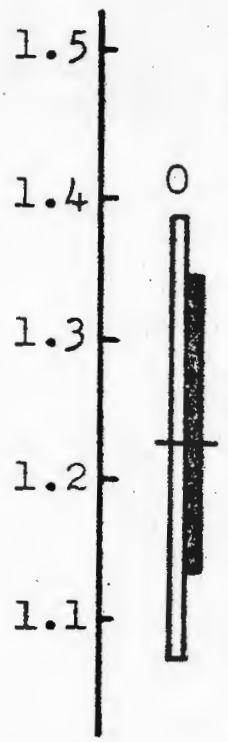

I

M
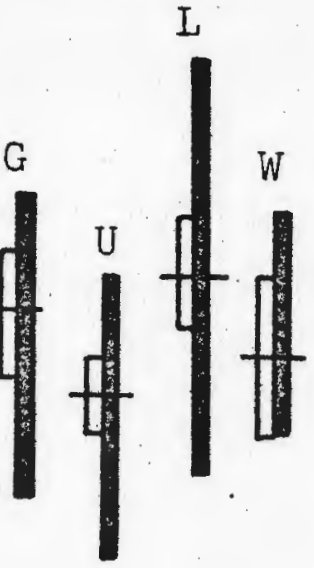

FIRST LOWER INCISOR LENGTH (mm)

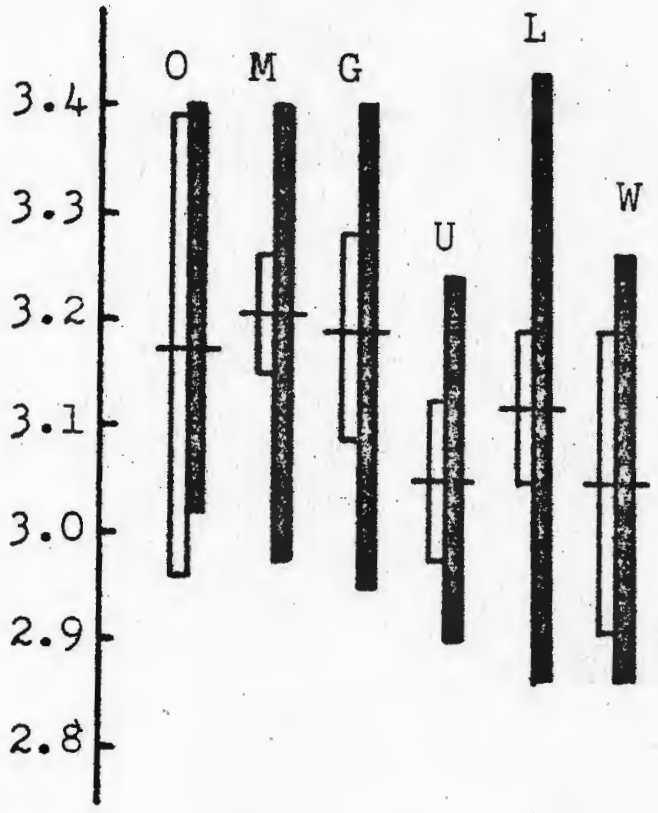

$\mathrm{U}=$ Upper Sand Island

$L=$ Lady Island

$W=$ Washington shore

Figure 18. Dental dimensions of first-year shrews from islands in the Columbia River and adjacent mainland shores. Short horizontal lines indicate the means, vertical solid bars the ranges, and vertical open bars the 99 percent confidence intervals for the means. 

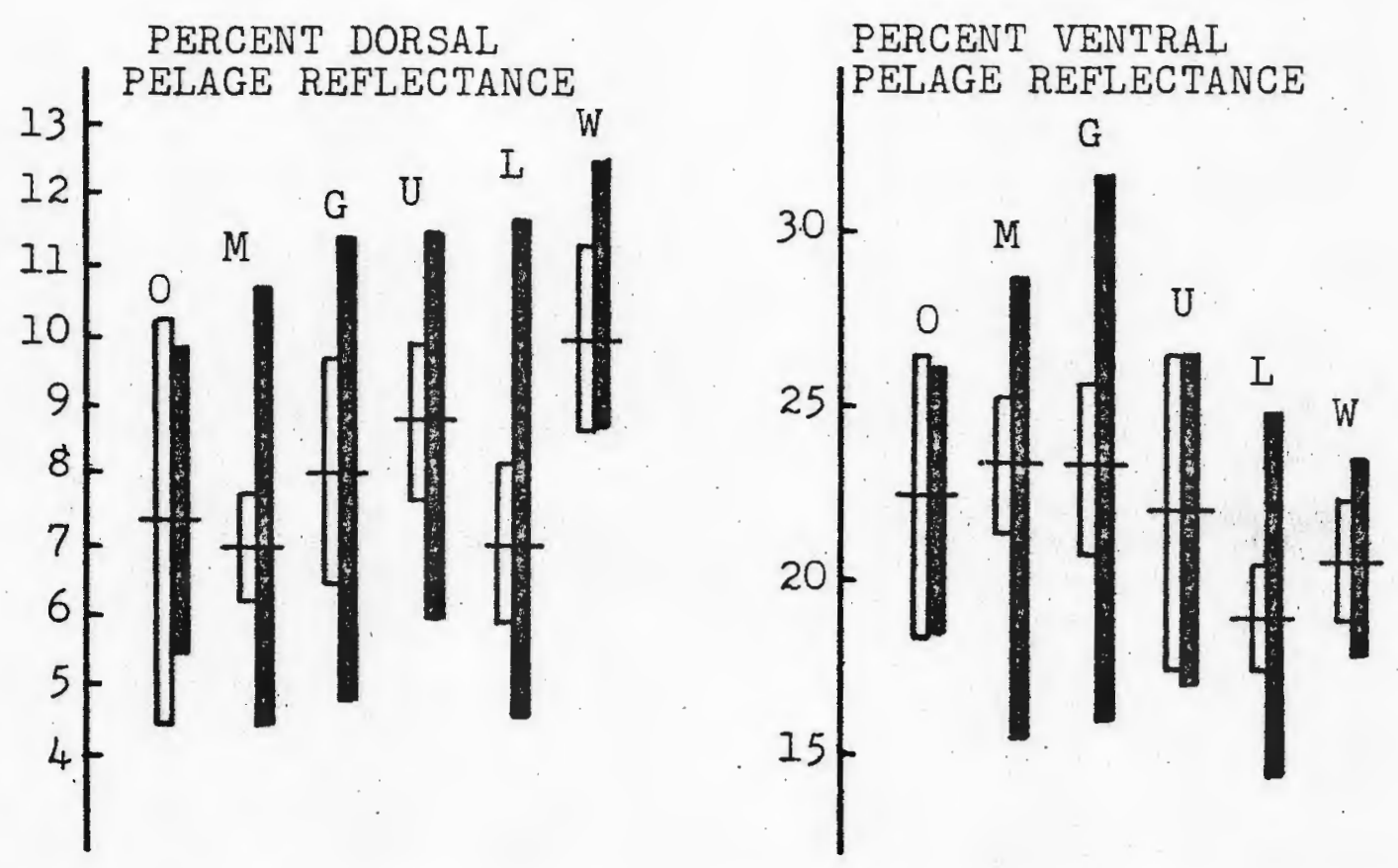

$$
\begin{array}{ll}
O=\text { Oregon shore } & U=\text { Upper Sand Island } \\
M=\text { McGuire Island } & \mathrm{L}=\text { Lady Island } \\
G=\text { Government Island } & W=\text { Washington shore }
\end{array}
$$

Figure 19. Pelage reflectance in first-year shrews from islands in the Columbia. River and adjacent mainland shores. Short horizontal lines indicate the means, vertical solid bars the ranges, and vertical open bars the 99 percent confidence intervals for the means. 

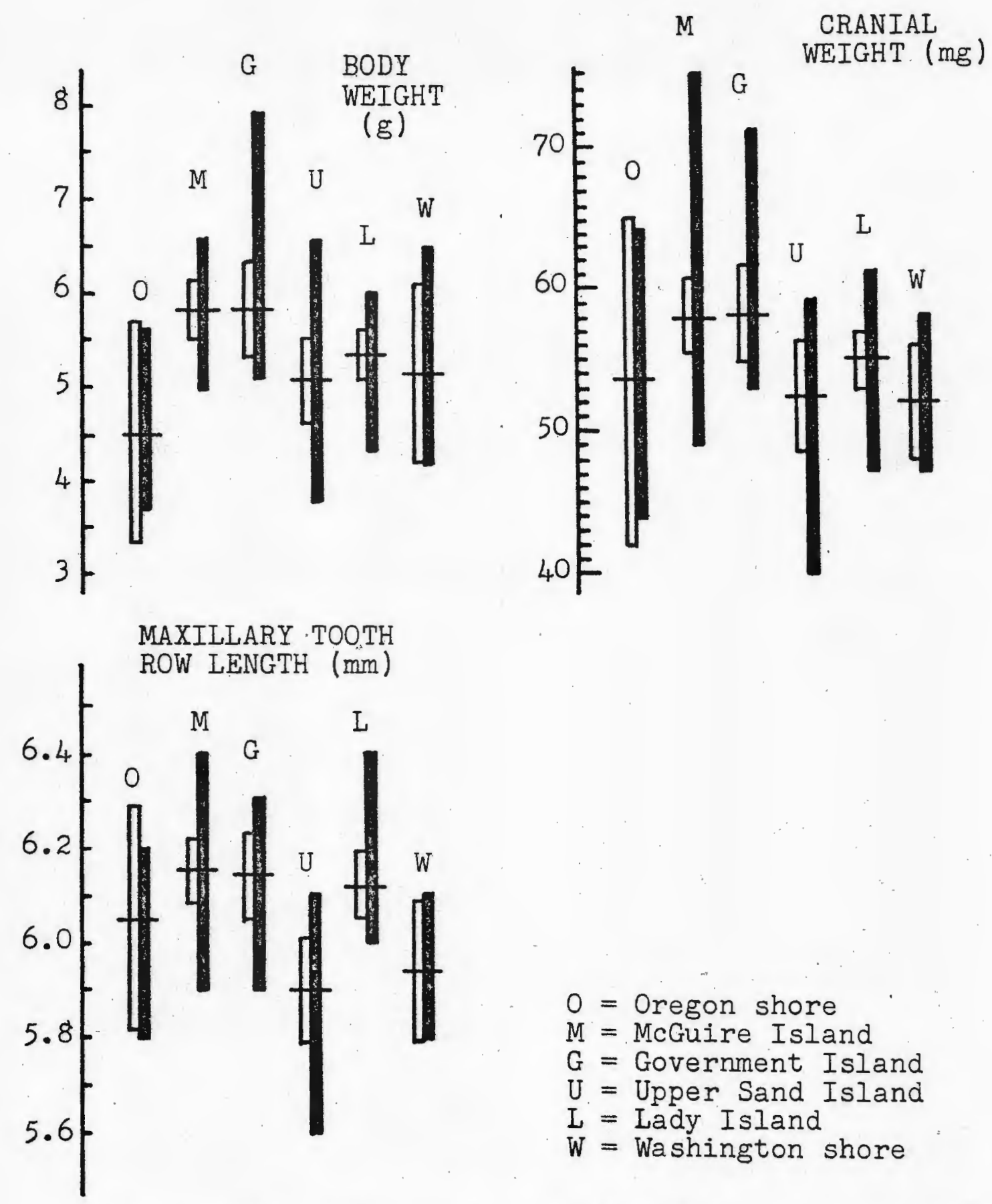

$$
\begin{aligned}
& O=\text { Oregon shore } \\
& M=\text { McGuire Island } \\
& G=\text { Government Island } \\
& U=\text { Upper Sand Island } \\
& \mathrm{L}=\text { Lady Island } \\
& W=\text { Washington shore }
\end{aligned}
$$

Figure 20. Body weight, cranial weight, and maxillary tooth row length in first-year shrews from islands in the Columbia River and adjacent mainland shores. Short horizontal lines indicate the means, vertical solid bars the ranges, and vertical open bars the 9.9 percent confidence intervals for the means. 


\begin{tabular}{|c|c|c|c|c|c|}
\hline 0 & & & & & \\
\hline 1.50 & M & & 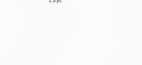 & & \\
\hline 1.59 & .50 & G & & & \\
\hline 1.32 & 1.61 & 1.75 & $\mathrm{U}$ & & \\
\hline 1.57 & 1.23 & 1.10 & 1.56 & I & \\
\hline 1.52 & 1.65 & 1.62 & .84 & 1.28 & W \\
\hline
\end{tabular}

$$
\begin{array}{ll}
O=\text { Oregon shore } & U=\text { Upper Sand Island } \\
M=\text { McGuire Island } & \mathrm{L}=\text { Lady Island } \\
\mathrm{G}=\text { Government Island } & W=\text { Washington shore }
\end{array}
$$

Figure 21. Average taxonomic distances between firstyear shrews from islands in the Columbia River and adjacent mainland shores. Calculations are based on standardized character means. 
3) the shrews on Upper Sand Island show closest affinity to those on the Washington shore;

4) the affinity of shrews on Lady Island is not clear, but they seem closest to those on Government Island.

In considering gene flow across a physical barrier like water, it is logical to ask how the genes flow, or, how the shrews move between the land masses. The fact that the river occasionally freezes over suggests the possibility of crossings over the ice. Shrews have been observed to cross the Yukon River on ice by tunneling just under the snow (Nelson, 1887; cited by Jackson, 1928). However, they are also known to freeze to death during unusually cold weather (Murie, cited by Jackson, 1928). Since the Columbia River is likely to freeze in the vicinity of the islands only during unusually cold weather and may not remain frozen long enough for snow to accumulate, ice crossings by shrews do not seem likely as important means of access to the islands.

Shrews also have been observed by Eskimos on sea ice (Jackson, 1928). I have seen ice cak@'s on the Columbia River, but their low freeboard makes them unlikely vehicles for shrews. Exposure to both ice and cold water would mitigate against a shrew's survival.

Direct swimming between lake islands has been documented for the white-footed mouse, Peromyscus leucopus, by Sheppe (1965). Jackson (1928) stated that shrews are 
good swimmers when "occasion demands it of them," but he cites no direct observations of swimming in non-aquatic forms. On two occasions I was able to determine the approximate time a shrew (Sorex vagrans) fell into a pitfall with water in the bottom and the time before which it died; in neither case did the shrew survive longer than about 20 minutes. The shrews appeared to be inept swimmers and seemed to have difficulty keeping their snouts out of the water. Whether their deaths were due to drowning or to "shock" (Jackson, 1928) is not clear. Even if the shrews were good swimmers, and assuming they have good vision, the low profiles of the islands would make visual orientation toward them difficult. Sheppe (1965) found such visual orientation important for swimming Peromyscus leucopus. That the Lady Island shrews differ from those on the Washington shore even though the two populations are separated by the narrow, slow-moving, and sheltered Camas Slough is further evidence that swimming probably is not an important means of access to the islands for shrews.

Rafting on floating vegetation or debris is a mode of water transportation often hypothesized for small mammals. Direct observations are few, but one is that of McCabe and Cowan (1945), who reported the sighting of a red squirrel on two logs floating on an open sound off the British Columbia coast. Cowan (1941) speculated that rafting was an important way in which shrews reached offshore islands in 
British Columbia. Rising water (tide) has been observed to drive shrews onto driftwood (Jackson, 1928), so imagining embarkation of a shrew on such a raft is not difficult. During the summer high-water period on the Columbia River many "rafts" of logs, uprooted trees, etc. are carried down the river. I have searched several of these without seeing any terrestrial vertebrates, but some could provide dry hiding places for small mammals. Rafting seems likely to be an important means of access to the river islands for shrews.

In light of the foregoing discussion, I offer the following explanation of the results. The shrews on Upper Sand Island are derived from ancestors which rafted from the Washington shore relatively recently. The apparent formation of the island in place within the last 100 years or so, the apparent lack of a land connection with the mainland or other islands since its formation, and the similarities between shrews from the island and mainland populations all support this contention. Dissimilarities between Upper Sand Island and Washington shore shrews may be the result of a founder effect (Mayr, 1966), genetic drift since colonization, natural selection since colonization, or a combination of these.

The shrews on Lady, Government, and McGuire Islands differ more from the mainland populations than those on Upper Sand Island. Historical evidence indicates Lady 
Island and the Government-McGuire island group have been in existence longer than Upper Sand Island, so they probably were colonized earlier than Upper Sand Island. The greater divergence therefore must be the result of genetic drift or natural selection. If it were due to a founder effect alone, the shrews on the older islands would be no more different from the mainland populations than those on Upper Sand Island. The common trend on the islands toward larger body size indicates natural selection is probably operating. If the larger size were due to favorable habitats on the islands and had no genetic basis, then the shrews on Upper Sand Island should be larger too. If the differences between island shrews and mainland shrews were due to genetic drift, the common trend on the islands toward larger size would not be expected. It seems that the founder effect, genetic drift, and natural selection all contributed to the divergence of the island populations.

The similarity between shrews on McGuire and Government Islands is probably due to migration over an earlier high-water connection between the islands, over the present low-water connection, or both.

The lack of pronounced dissimilarity between shrews from opposite mainland shores may be an artifact of the small samples drawn from those populations, but I think it is probably real. The gene pools on the mainlands are much 
larger than those on the islands, and large gene pools tend to resist natural selection and genetic drift (Mayr, 1966). The much longer shorelines of the mainlands relative to the islands may result in a higher rate of migration between opposite mainland shores than between the mainland shores and the islands. 


\section{CONCLUSIONS}

1. The Columbia River serves as an incomplete barrier to gene flow between populations of Sorex vagrans. Its barrier effect is sufficient to allow divergence of island populations, or, possibly, to preserve differences which are a result of the founder effect.

2. Natural selection on the small gene pools on the islands has probably played a role in the divergence of island shrews from their ancestral stock on the mainlands.

3. Rafting on floating vegetation and debris during the summer high-water period is the most likely means of access to the islands for shrews.

4. Morphometric comparison of island populations provides a more sensitive indication of restricted gene flow than similar comparison of opposite mainland populations. 


\section{LITERATURE CITED}

Bailey, N. T. J. 1959. Statistical methods in biology • John Wiley and Sons, Inc., New York. $x+199$ p.

Baldwin, E. M. 1966. Geology of the Columbia River Gorge. Northwest Sci., 40: 121-128.

Cameron, A. W. 1958. Mammals of the islands of the Gulf of St. Lawrence. Natl. Mus. Can., Bull. No. 154: iv + $165 \mathrm{p}$.

Columbia Basin Interagency Committee. 1966. Columbia River water temperature conditions and research requirements. Report of the Task Force on Water Temperature Evaluation of the Water Supply and Water Pollution Control Subcommittee. vi $+58 \mathrm{p}$.

Cowan, I. M. 1941. Insularity in the genus Sorex on the north coast of British Columbia. Proc. Biol. Soc. Wash., 54: 45-108.

Dice, L. R. 1925. The mammals of Marion Island, Grand Traverse County, Michigan. Occas. Pap. Mus. Zool. Univ. Michigan, 160: 1-8.

Findley, J. S. 1955. Speciation of the wandering shrew. Univ. Kansas Publ., Mus. Nat. Hist., 9(1): 1-68.

Fox, W. 1948. Variation in the deer-mouse (Peronyscus maniculatus) along the lower Columbia River. Amer. Midl. Nat., 40: 420-452.

Goldman, E. A. 1931. New pocket gophers from Arizona and Utah. J. Wash. Acad. Sci., $21:$ 416-426.

Goldman, E. A. 1937. The Colorado River as a barrier in mammalian distribution. J. Mamm., 18: 427-435.

Gordon, K. 1966. Mammals and the influence of the Columbia River Gorge on their distribution. Northwest Sci., 40: $142-146$.

Grinnell, J. and J. E. Hill. 1936. Pocket gophers

(Thomomys) of the Lower Colorado Valley. J. Mamm., 
Hall, E. R. 1938. Variation among insular mammals of Georgia Strait, British Columbia. Amer. Nat., 72: $453-463$.

Hall, E. R. 1962. Collecting and preparing study specimens of vertebrates. Univ. Kansas Mus. Nat. Hist. Misc. Publ. No. $30,46 . \mathrm{p}$.

Hall, E. R. and K. R. Kelson. 1959. The mammals of North America. Ronald Press, New York. 1083 p.

Hoel, P. G. 1960. Elementary statistics. John Wiley and Sons, Inc., New York. vii + 261 p.

Jackson, H. H. T. 1928. A taxonomic review of the American long-tailed shrews (Genera Sorex and Microsorex). N. Amer. Fauna No. 5l, vi +238 p.

Kelsoin, K. R. 1951. Speciation in rodents of the Colorado River drainage. Univ. Utah Biol. Ser., ll(3): viii + $125 \mathrm{p}$.

Kirk, G. 1976. A survey of small mammals on islands in the Columbia and Willamette Rivers. M. S. Thesis, Portland State University. iv $+17 \mathrm{p}$.

Lockley, F. 1928. History of the Columbia River Valley from The Dalles to the sea. S. J. Clarke Publ. Co., Chicago. Vol. I, $1105 \mathrm{p}$.

Manville, R. H. 1942. Notes on the mammals of Mount Desert Island, Maine. J. Mamm., 23: 391-398.

Manville, R. H. 1950. The mammals of Drummond Island, Michigan. J. Mamm., 31: 358-359.

Manville, R. H. 1964. The vertebrate fauna of Isle au Haut, Maine. Amer. Midl. Nat., 72: 396-407.

Mayr, E. 1966. Animal species and evolution. Harvard Univ. Press, Cambridge. xvi +797 p.

McCabe, T. T. and I. M. Cowan. 1945 Meromyscus maniculatus macrorhinus and the problem of insularity. Trans. Roy. Can. Inst., 25: 117-215.

Nelson, E. W. 1887. Report upon natural history collections made in Alaska between the years 1877 and 1881. Arctic ser. publ. issued in connection with Signal Service, U. S. Army, No. 3. 
Pacific Northwest River Basins Commission. 1969. Climatological handbook. Columbia Basin states. Temperature. Vol. I, Pt. B. Vancouver, Washington. viii + $568 \mathrm{p}$.

Pruitt, W. 0. 1951. Mammals of the Chase S. Osborn Preserve, Sugar Island, Michigan. J. Mamm., 32: 470-472.

Rantz, S. E. and H. C. Riggs. 1949. Magnitude and frequency of floods in the Columbia River Basin in U. S. Geological Survey, Floods of May-June 1948 in Columbia River Basin. Geological Survey Water-Supply Paper 1080, viii $+476 \mathrm{p}$.

Shapley, D. 1976. Crops and climatic change: USDA's forecasts criticized. Science, 193: 1222-1224.

Sheppe, W. 1965. Island populations and gene flow in the deer mouse, Peromyscus leucopus. Evolution, 19: 480495 .

Sneath, P. H. A. and R. R. Sokal. 1973. Numerical taxonomy. W. H. Freeman and Co., San Francisco. xvi $+573 \mathrm{p}$.

Thwaites, R. G. (ed.) 1959. Original journals of the Lewis and Clark Expedition 1804-1806. Antiquarian Press, Ltd., New York. Vol. 3, $x+363$ p.

U. S. Coast and Geodetic Survey. 1904. Columbia River, Vancouver to Reed Island. (topographic map 6143)

U. S. Coast and Geodetic 'Survey. 1921. Columbia River', Vancouver to Reed Island. (topographic map)

U. S. Coast and Geodetic Survey. 1937. Columbia River, Vancouver to Reed Island. (topographic map)

U. S. Department of Commerce. 1974. Columbia River, Harrington Point to Crims Island. National Oceanic and Atmospheric Administration, National Ocean Survey Chart No. 18523, 34th ed., 7 December.

U. S. Department of Commerce. 1975a. Columbia River, Crims Island to Saint Helens, and Saint Helens to Vancouver. National Oceanic and Atmospheric Administration, National Ocean Survey Chart No. 18524, Sides A and B, l2th ed., 1 March.

U. S. Department of Commerce. 1975b. Columbia River, Pacific Ocean to Harrington Point. National Oceanic and Atmospheric Administration, National Ocean Survey Chart No. 18521, 46th ed., 26 April. 
U. S. Department of Commerce. 1975c. Columbia River, Vancouver to Bonneville Dam. National Oceanic and Atmospheric Administration, National Ocean Survey Chart No. 18531, Side A, IIth ed., 3 May.

U. S. Geological Survey. 1954. Camas Quadrangle, Washington-Oregon. (topographic map)

U. S. Geological Survey. 1961. Camas Quadrangle, OregonWashington. Southwest quarter of 15-minute section. (topographic map) 


\section{APPENDIX}

The tables which follow summarize the morphometric data for vagrant shrews, Sorex vagrans vagrans Baird, from islands in the Columbia River and from adjacent mainland shores. The method of distinguishing first- and secondyear animals is described in the text. No second-year shrews were taken from the Washington shore population. 


\section{TABLE III}

MORPHOMETRY OF FIRST-YEAR SHREWS FROM THE OREGON SHORE OF THE COLUMBIA RIVER NEAR

MCGUIRE ISLAND

CHARACTER
total length (mm)
tail length (mm)
hind foot length (mm)
body weight (g)
overall cranial length (mm)
condylobasal length (mm)
maximum cranial breadth (mm)
interorbital breadth (mm)
maxillary breadth. (mm)
condyloinfraorbital length (mm)
maxillary tooth row length (mm)
palatal length (mm)
cranial depth (mm)
cranial weight fmg)
first upper incisor height (mm)
first upper incisor length (mm)
first lower molar height (mm)
first lower incisor length (mm)
maximum tail tip hair length (mm)
dorsal pelage reflectance (\%)
ventral pelage reflectance (\%).

\section{SAMPLE \\ SIZE}

$\begin{array}{lc}6 & 93-107 \\ 6 & 39-43 \\ 6 & 12-13 \\ 6 & 3.70-5.61 \\ 6 & 16.79-17.87 \\ 6 & 15.99-17.16 \\ 6 & 8.05=8.78 \\ 6 & 3.00-3.18 \\ 6 & 4.59-5.33 \\ 6 & 11.87-12.91 \\ 6 & 5.8-6.2 \\ 6 & 6.2-7.0 \\ 6 & 4.82-5.40 \\ 6 & 44=64 \\ 6 & 1.27-1.67 \\ 6 & 1.13-1.34 \\ 6 & 1.09-1.24 \\ 6 & 3.02=3.40 \\ 6 & 3.2-6.4 \\ 6 & 5.4=9.8 \\ 6 & 18.5-26.0\end{array}$

MEAN

97.5

40.7

12.5

4.513

17.257

16.442

8.443

3.098

4. 925

12.302

6.05

6.60

5.093

53.5

1.447

1.225

1.193

3.172

4.43

7.33

22.35

STANDARD DEVIATION

$$
\begin{aligned}
& 5.43 \\
& 1.63 \\
& .55 \\
& .7234 \\
& .4371 \\
& .4455 \\
& .2521 \\
& .0778 \\
& .2424 \\
& .8902 \\
& .138 \\
& .261 \\
& .1922 \\
& 7.06 \\
& .1418 \\
& .0965 \\
& .0568 \\
& .1314 \\
& 1.223 \\
& 1.764 \\
& 2.422
\end{aligned}
$$

COEFFICIENT OF VARIABIIITY

5.57

4.00

4.40

5.86

2.53

2.71

2.99

2.51

4.92

7.24

2.28

3.95

3.77

13.20

9.80

7.88

4.76

4.14

27.61

24.07

10.84 


\section{TABLE IV}

MORPHOMETRY OF FIRST-YEAR SHREWS FROM MCGUIRE ISLAND

\begin{tabular}{|c|c|c|c|c|c|}
\hline & SAMPLE & & & STANDARD & COEFFICIENT \\
\hline CHARACTER & SIZE & RANGE & MEAN & DEVIATION & OF VARIABILITY \\
\hline $\begin{array}{l}\text { total length (mm) } \\
\text { tail length (mm) } \\
\text { hind foot length (mm) } \\
\text { body weight ( } \mathrm{g}) \\
\text { overall cranial length (mm) } \\
\text { condylobasal length (mm) } \\
\text { maximum cranial breadth (mm) } \\
\text { interorbital breadth (mm) } \\
\text { maxillary breadth (mm) } \\
\text { condyloinfraorbital length (mm) } \\
\text { maxillary tooth row length (mm) } \\
\text { palatal length (mm) } \\
\text { cranial depth (mm) } \\
\text { cranial weight (mg) } \\
\text { first upper incisor height (mm) } \\
\text { first upper incisor length (mm) } \\
\text { first lower molar height (mm) } \\
\text { first lower incisor length }(\mathrm{mm}) \\
\text { maximum tail tip hair length (mm) } \\
\text { dorsal pelage reflectance }(\%) * \\
\text { ventral pelage reflectance }(\%)\end{array}$ & $\begin{array}{l}26 \\
26 \\
26 \\
26 \\
26 \\
26 \\
26 \\
26 \\
24 \\
26 \\
26 \\
26 \\
26 \\
26 \\
26 \\
26 \\
27 \\
27 \\
27 \\
27 \\
27\end{array}$ & $\begin{aligned} & 93-110 \\
& 38-46 \\
& 12-14 \\
& 4.97-6.55 \\
& 17.04=18.13 \\
& 16.27=17.32 \\
& 8.04=8.79 \\
& 3.07=3.60 \\
& 4.82=5.59 \\
& 12.13=13.05 \\
& 5.9=6.4 \\
& 6.5=7.0 \\
& 4.92=5.52 \\
& 49=75 \\
& 1.27=1.62 \\
& 1.14=1.45 \\
& 1.05=1.29 \\
& 2.98=3.40 \\
& 1.4=4.6 \\
& 4.4=10.6 \\
& 15.5=28.7\end{aligned}$ & $\begin{array}{l}102.7 \\
41.8 \\
12.8 \\
5.805 \\
17.588 \\
16.792 \\
8.337 \\
3.271 \\
5.029 \\
12.559 \\
6.15 \\
6.72 \\
5.199 \\
58.0 \\
1.443 \\
1.275 \\
1.136 \\
3.204 \\
3.26 \\
6.93 \\
23.32\end{array}$ & $\begin{array}{l}4.91 \\
. .09 \\
.45 \\
.5344 \\
.3098 \\
.2960 \\
.1692 \\
.1223 \\
.1602 \\
.2253 \\
.121 \\
.156 \\
.1330 \\
4.99 \\
.0786 \\
.0270 \\
.0303 \\
.1011 \\
.708 \\
1.483 \\
3.588\end{array}$ & $\begin{array}{r}4.78 \\
5.00 \\
3.52 \\
9.21 \\
1.76 \\
1.76 \\
2.03 \\
3.74 \\
3.19 \\
1.79 \\
1.97 \\
2.32 \\
2.56 \\
8.60 \\
5.45 \\
2.12 \\
2.67 \\
3.16 \\
21.72 \\
21.40 \\
15.39\end{array}$ \\
\hline
\end{tabular}

- In the case of molting shrews, the lower of the two reflectances was used in the calculations. 
TABLE V

MORPHOMETRY OF FIRST-YEAR SHREWS FROM GOVERMMENT ISIAND

\begin{tabular}{|c|c|c|c|c|c|}
\hline CHARACTER & $\begin{array}{l}\text { SAMPLE } \\
\text { SIZE }\end{array}$ & RANGE & MEAN & $\begin{array}{l}\text { STANDARD } \\
\text { DEVIATION }\end{array}$ & $\begin{array}{c}\text { COEFFICIENT } \\
\text { OF VARIABILITY }\end{array}$ \\
\hline $\begin{array}{l}\text { total length (mm) } \\
\text { tail length (mm) } \\
\text { hind foot length (mm) } \\
\text { body weight ( } \mathrm{g}) \\
\text { overall cranial length (mm) } \\
\text { condylobasal length (mm) } \\
\text { maximum cranial breadth (mm) } \\
\text { interorbital breadth (mm) } \\
\text { maxillary breadth (mm) } \\
\text { condyloinfraorbital length (mm) } \\
\text { maxillary tooth row length (mm) } \\
\text { palatal length (mm) } \\
\text { cranial depth (mm) } \\
\text { cranial weight (mg) } \\
\text { first upper incisor height (mm) } \\
\text { first upper incisor length (mm) } \\
\text { first lower molar height }(\mathrm{mm}) \\
\text { first lower incisor length }(\mathrm{mm}) \\
\text { maximum tail tip hair length (mm) } \\
\text { dorsal pelage reflectance }(\%) . * \\
\text { ventral pelage reflectance }(\%)\end{array}$ & $\begin{array}{l}16 \\
16 \\
16 \\
16 \\
16 \\
16 \\
16 \\
16 \\
16 \\
16 \\
16 \\
16 \\
16 \\
16 \\
16 \\
16 \\
16 \\
16 \\
16 \\
16 \\
16 \\
16\end{array}$ & $\begin{array}{r}97-114 \\
38=48 \\
12=14 \\
5.10=7.90 \\
16.97=18.10 \\
16.33=17.50 \\
7.98=8.78 \\
3.02=3.35 \\
4.60=5.14 \\
12.11=12.92 \\
5.9=6.3 \\
6.6=7.0 \\
4.83=5.45 \\
53=71 \\
1.16=1.58 \\
1.14=1.36 \\
.93=1.24 \\
2.95=3.40 \\
1.6=4.6 \\
4.7=11.3 \\
16.1=31.4\end{array}$ & $\begin{array}{l}103.9 \\
43.1 \\
13.1 \\
5.825 \\
17.594 \\
16.839 \\
8.348 \\
3.212 \\
4.972 \\
12.577 \\
6.14 \\
6.78 \\
5.205 \\
58.1 \\
1.420 \\
1.274 \\
1.123 \\
3.185 \\
3.19 \\
7.99 \\
23.17\end{array}$ & $\begin{array}{l}4.68 \\
2.91 \\
.45 \\
.6598 \\
.3152 \\
.3276 \\
.2464 \\
.1006 \\
.1385 \\
.2602 \\
.126 \\
.129 \\
.1500 \\
4.50 \\
.1232 \\
.0661 \\
.0763 \\
.1244 \\
.821 \\
2.188 \\
3.348\end{array}$ & $\begin{array}{r}4.50 \\
6.75 \\
3.44 \\
11.33 \\
1.79 \\
1.95 \\
2.95 \\
3.13 \\
2.79 \\
2.07 \\
2.05 \\
1.90 \\
2.88 \\
7.76 \\
8.68 \\
5.19 \\
6.79 \\
3.91 \\
25.74 \\
27.38 \\
14.45\end{array}$ \\
\hline
\end{tabular}

- In the case of molting shrews, the lower of the two reflectances was used in the calculations. 
TABLE VI

MORPHOMETRY OF FIRST-YEAR SHREWS FROM UPPER SAND ISLAND

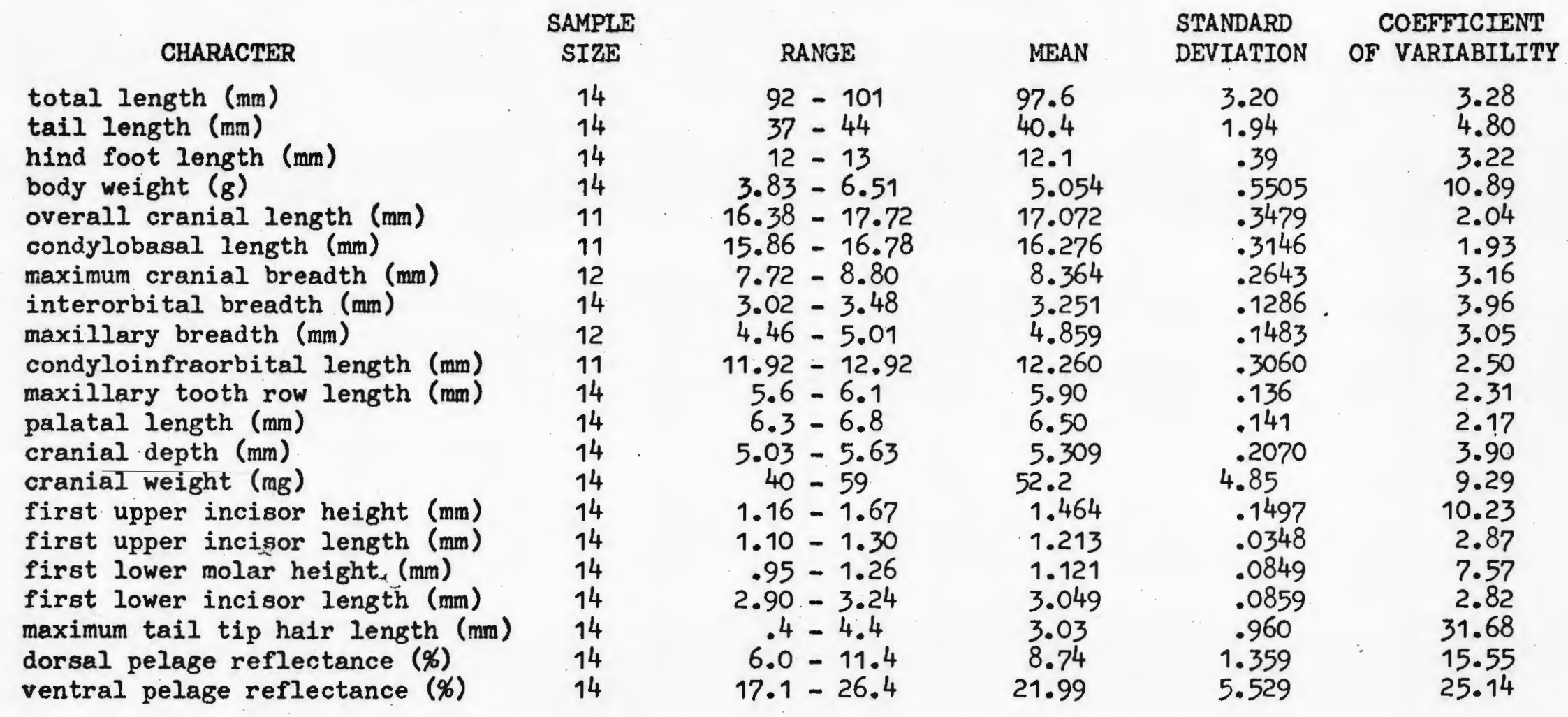


TABLE VII

MORPHOMETRY OF FIRST-YEAR SHREWS FROM LADY ISIAND

\begin{tabular}{|c|c|c|c|c|c|}
\hline CHARACTER & $\begin{array}{c}\text { SAMPLE } \\
\text { SIZE }\end{array}$ & RANGE & MEAN & $\begin{array}{l}\text { STANDARD } \\
\text { DEVIATION }\end{array}$ & $\begin{array}{l}\text { COEFFICIENT } \\
\text { OF VARIABILITY }\end{array}$ \\
\hline $\begin{array}{l}\text { total length (mm) } \\
\text { tail length (mm) } \\
\text { hind foot length (mm) } \\
\text { body weight (g) } \\
\text { overall cranial length (mm) } \\
\text { condylobasal length (mm) } \\
\text { maximum cranial breadth (mm) } \\
\text { interorbital breadth (mm) } \\
\text { maxillary breadth (mm) } \\
\text { condyloinfraorbital length (mm) } \\
\text { maxillary tooth row length (mm) } \\
\text { palatal length (mm) } \\
\text { cranial depth (mm) } \\
\text { cranial weight (mg) } \\
\text { first upper incisor height (mm) } \\
\text { first upper incisor length (mm) } \\
\text { first lower molar height (mm) } \\
\text { first lower incisor length (mm) } \\
\text { maximum tail tip hair length (mm) } \\
\text { dorsal pelage reflectance }(\%) * \\
\text { ventral pelage reflectance }(\%)\end{array}$ & $\begin{array}{l}20 \\
20 \\
20 \\
20 \\
20 \\
20 \\
20 \\
20 \\
19 \\
20 \\
20 \\
20 \\
20 \\
20 \\
19 \\
19 \\
20 \\
20 \\
20 \\
20 \\
20\end{array}$ & $\begin{array}{c}90-107 \\
38-47 \\
12-14 \\
4.31-5.96 \\
17.00-17.86 \\
16.34-17.16 \\
7.88-8.75 \\
3.06-3.36 \\
4.54-5.23 \\
11.94-12.89 \\
6.0=6.4 \\
6.4-6.9 \\
4.93-5.95 \\
47-61 \\
1.08-1.43 \\
1.16-1.45 \\
1.05-1.19 \\
2.86-3.43 \\
.8-3.8 \\
4.6=11.6 \\
14.5-24.7\end{array}$ & $\begin{array}{c}97.2 \\
43.2 \\
12.9 \\
5.349 \\
17.432 \\
16.756 \\
8.345 \\
3.186 \\
4.858 \\
12.445 \\
6.12 \\
6.70 \\
5.240 \\
54.9 \\
1.277 \\
1.301 \\
1.114 \\
3.119 \\
2.76 \\
6.96 \\
18.90\end{array}$ & $\begin{array}{l}4.20 \\
2.44 \\
.56 \\
.4091 \\
.2782 \\
.2492 \\
.2012 \\
.0841 \\
.1526 \\
.2373 \\
.107 \\
.136 \\
.2162 \\
3.04 \\
.0722 \\
.0568 \\
.0406 \\
.1140 \\
.679 \\
1.723 \\
2.405\end{array}$ & $\begin{array}{r}4.32 \\
5.65 \\
4.34 \\
7.65 \\
1.60 \\
1.49 \\
2.41 \\
2.64 \\
3.14 \\
1.91 \\
1.75 \\
2.03 \\
4.13 \\
5.54 \\
5.65 \\
4.37 \\
3.64 \\
3.66 \\
24.60 \\
24.76 \\
12.72\end{array}$ \\
\hline
\end{tabular}

- In the case of molting shrews, the lower of the two reflectances was used in the calculations. 
MORPHOMETRY OF FIRST-YEAR SHREWS FROM THE WASHINGTON SHORE OF THE COLUMBIA RIVER NEAR

IADY ISLAND

\section{CHARACTER}

total length (mm)

tail length (mm)

hind foot length (mm)

body weight $(\mathrm{g})$

overall cranial length (mm)

condylobasal length (mm)

maximum cranial breadth (mm)

interorbital breadth (mm)

maxillary breadth (mm)

condyloinfraorbital length (mm)

maxillary tooth row length (mm)

palatal length ( $\mathrm{mm}$ )

cranial depth (mm)

cranial weight (mg)

first upper incisor height (mm)

first upper incisor length (mm)

first lower molar height (mm)

first lower incisor length (mm)

maximum tail tip hair length (mm)

dorsal pelage reflectance (\%)

ventral pelage reflectance (\%)

SAMPL
SIZE
9
9
9
9
9
9
8
9
8
9
9
9
9
9
9
9
9
9
9
9
9

$$
\begin{gathered}
\text { RANGE } \\
94-102 \\
39-45 \\
12-13 \\
4.16-6.45 \\
16.74-17.88 \\
15.98-16.94 \\
7.70-8.48 \\
3.09-3.30 \\
4.68-5.01 \\
11.96-12.69 \\
5.8-6.1 \\
6.4-6.8 \\
5.07-5.65 \\
47-58 \\
1.25-1.65 \\
1.18-1.34 \\
1.02-1.21 \\
2.86-3.26 \\
1.6-4.8 \\
8.7-12.4 \\
18.0-23.4
\end{gathered}
$$

MEAN

97.4

42.1

12.6

5.126

17.204

16.398

8.190

3.219

4.849

12.232

5.94

6.52

5. 381

51.9

1. 380

1.242

1. 122

3.047

3.31

9.93

20.51

$\begin{array}{cc}\text { STANDARD } & \text { COEFICIENT } \\ \text { DEVIATION } & \text { OF VARIABIIITY } \\ 2.55 & 2.62 \\ 1.90 & 4.51 \\ .50 & 3.97 \\ .8430 & 16.45 \\ .3502 & 2.04 \\ .2927 & 1.78 \\ .3025 & 3.69 \\ .0809 & 2.51 \\ .1105 & 2.28 \\ .2227 & 1.82 \\ .132 & 2.22 \\ .132 & 2.02 \\ .2349 & 4.37 \\ 3.59 & 6.92 \\ .1275 & 9.24 \\ .0522 & 4.20 \\ .0682 & 6.08 \\ .1239 & 4.07 \\ 1.078 & 32.57 \\ 1.169 & 11.77 \\ 1.558 & 7.60 \\ & \end{array}$


MORPHOMETRY OF SECOND-YEAR SHREWS FROM THE OREGON SHORE OF THE COLUMBIA RIVER NEAR

MCGUIRE ISLAND

\begin{tabular}{|c|c|c|c|c|c|}
\hline CHARACTER & $\begin{array}{l}\text { SAMPLE } \\
\text { SIZE }\end{array}$ & RANGE & MEAN & $\begin{array}{l}\text { STANDARD } \\
\text { DEVIATION }\end{array}$ & $\begin{array}{l}\text { COEFFICIENT } \\
\text { OF VARIABILITY }\end{array}$ \\
\hline $\begin{array}{l}\text { total length (mm) } \\
\text { tail length (mm) } \\
\text { hind foot length (mm) } \\
\text { body weight (g) } \\
\text { overall cranial length (mm) } \\
\text { condylobasal length (mm) } \\
\text { maximum cranial breadth (mm) } \\
\text { interorbital breadth (mm) } \\
\text { maxillary breadth (mm) } \\
\text { condyloinfraorbital length (mm) } \\
\text { maxillary tooth row length (mm) } \\
\text { palatal length (mm) } \\
\text { cranial depth (mm) } \\
\text { cranial weight (mg) } \\
\text { first upper incisor height (mm) } \\
\text { first upper incisor length (mm) } \\
\text { first lower molar height (mm) } \\
\text { first lower incisor length (mm) } \\
\text { maximum tail tip hair length (mm) } \\
\text { dorsal pelage reflectance ( } \%) \\
\text { ventral pelage reflectance (\%) }\end{array}$ & $\begin{array}{l}4 \\
4 \\
4 \\
4 \\
4 \\
4 \\
4 \\
4 \\
3 \\
4 \\
4 \\
4 \\
4 \\
4 \\
4 \\
4 \\
4 \\
4 \\
4 \\
4 \\
4\end{array}$ & $\begin{array}{c}96-109 \\
36-44 \\
12-13 \\
4.87-7.22 \\
16.06-17.00 \\
15.53-16.80 \\
8.00-8.57 \\
3.00-3.33 \\
4.91-4.95 \\
11.62-12.67 \\
5.6-6.0 \\
6.3-6.7 \\
4.72-5.03 \\
49-63 \\
.70-.92 \\
1.10=1.32 \\
2.48-2.81 \\
0=2.4 \\
7.0-9.5 \\
18.4=23.5\end{array}$ & $\begin{array}{c}103.2 \\
39.2 \\
12.2 \\
6.288 \\
16.725 \\
16.350 \\
8.258 \\
3.150 \\
4.927 \\
12.172 \\
5.78 \\
6.50 \\
4.828 \\
55.2 \\
.788 \\
1.165 \\
.760 \\
2.630 \\
.70 \\
8.40 \\
19.92\end{array}$ & $\begin{array}{l}6.29 \\
3.59 \\
.50 \\
1.0859 \\
.4476 \\
.5700 \\
.2438 \\
.1564 \\
.0208 \\
.4298 \\
.171 \\
.183 \\
.1379 \\
6.13 \\
.0957 \\
.1050 \\
0 \\
.1374 \\
1.137 \\
1.163 \\
2.395\end{array}$ & $\begin{array}{r}6.09 \\
9.16 \\
4.10 \\
17.27 \\
2.68 \\
3.49 \\
2.95 \\
4.97 \\
.42 \\
3.53 \\
2.96 \\
2.82 \\
2.86 \\
11.11 \\
12.14 \\
9.01 \\
0 \\
5.22 \\
162.43 \\
13.85 \\
12.02\end{array}$ \\
\hline
\end{tabular}


TABLE $\mathrm{X}$

MORPHOMETRY OF SECOND-YEAR SHREWS FROM MCGUIRE ISLAND

\begin{tabular}{|c|c|c|c|c|c|}
\hline CHARACTER & $\begin{array}{l}\text { SAMPLEE } \\
\text { SIZE }\end{array}$ & RANGE & MEAN & $\begin{array}{l}\text { STANDARD } \\
\text { DEVIATION }\end{array}$ & $\begin{array}{c}\text { COEFFICIENT } \\
\text { OF VARIABILITY }\end{array}$ \\
\hline $\begin{array}{l}\text { total length (mm) } \\
\text { tail length (mm) } \\
\text { hind foot length (mm) } \\
\text { body weight (g) } \\
\text { overall cranial length (mm) } \\
\text { condylobasal length (mm) } \\
\text { maximum cranial breadth (mm) } \\
\text { interorbital breadth (mm) } \\
\text { maxillary breadth (mm) } \\
\text { condyloinfraorbital length (mm) } \\
\text { maxillary tooth row length (mm) } \\
\text { palatal length (mm) } \\
\text { cranial depth (mm) } \\
\text { cranial weight (mg) } \\
\text { first upper incisor height (mm) } \\
\text { first upper incisor length (mm) } \\
\text { first lower molar height (mm) } \\
\text { first lower incisor length (mm) } \\
\text { maximum tail tip hair length (mm) } \\
\text { dorsal pelage reflectance }(\%) \\
\text { ventral pelage reflectance }(\%)\end{array}$ & $\begin{array}{l}10 \\
10 \\
10 \\
10 \\
10 \\
10 \\
10 \\
10 \\
10 \\
10 \\
10 \\
10 \\
10 \\
10 \\
10 \\
10 \\
10 \\
10 \\
10 \\
10 \\
10 \\
10\end{array}$ & $\begin{aligned} & 100-115 \\
& 37-45 \\
& 12=13 \\
& 6.47-8.23 \\
& 16.81-17.82 \\
& 16.35=17.51 \\
& 8.23=9.04 \\
& 3.15=3.36 \\
& 4.68=5.29 \\
& 12.12=13.07 \\
& 5.8=6.1 \\
& 6.6=7.0 \\
& 4.96=5.38 \\
& 56=71 \\
& .60=1.28 \\
& 1.10=1.30 \\
& .71=.88 \\
& 2.62=3.00 \\
& 0=1.0 \\
& 6.5=10.1 \\
& 12.7=26.8\end{aligned}$ & $\begin{array}{c}106.2 \\
41.0 \\
12.9 \\
7.329 \\
17.301 \\
16.898 \\
8.596 \\
3.269 \\
5.048 \\
12.662 \\
5.97 \\
6.77 \\
5.212 \\
65.0 \\
.853 \\
1.224 \\
.817 \\
2.797 \\
.18 \\
8.18 \\
18.74\end{array}$ & $\begin{array}{l}5.52 \\
2.49 \\
.33 \\
.3543 \\
.3496 \\
.3801 \\
.2641 \\
.0792 \\
.1623 \\
.3158 \\
.1059 \\
.1059 \\
.1378 \\
5.52 \\
.2170 \\
.0523 \\
.0506 \\
.1366 \\
.382 \\
1.316 \\
5.014\end{array}$ & $\begin{array}{r}5.20 \\
6.07 \\
2.56 \\
4.83 \\
2.02 \\
2.25 \\
3.07 \\
2.42 \\
3.22 \\
2.49 \\
1.77 \\
1.56 \\
2.64 \\
8.49 \\
25.44 \\
4.27 \\
6.19 \\
4.88 \\
212.22 \\
16.09 \\
26.76\end{array}$ \\
\hline
\end{tabular}


TABLE XI

MORPHOMETRY OF SECOND-YEAR SHREWS FROM GOVERNMENT ISLAND

\begin{tabular}{|c|c|c|c|c|c|}
\hline CHARACTER & $\begin{array}{l}\text { SAMPLE } \\
\text { SIZE }\end{array}$ & RANGE & MEAN & $\begin{array}{l}\text { STANDARD } \\
\text { DEVIATION }\end{array}$ & $\begin{array}{c}\text { COEFFICIENT } \\
\text { OF VARIABILITY }\end{array}$ \\
\hline $\begin{array}{l}\text { total length (mm) } \\
\text { tail length (mm) } \\
\text { hind foot length (mm) } \\
\text { body weight (g) } \\
\text { overall cranial length (mm) } \\
\text { condylobasal length (mm) } \\
\text { maximum cranial breadth (mm) } \\
\text { interorbital breadth (mm) } \\
\text { maxillary breadth (mm) } \\
\text { condyloinfraorbital length (mm) } \\
\text { maxillary tooth row length (mm) } \\
\text { palatal length (mm) } \\
\text { cranial depth (mm) } \\
\text { cranial weight (mg) } \\
\text { first upper incisor height (mm) } \\
\text { first upper incisor length (mm) } \\
\text { first lower molar height (mm) } \\
\text { first lower incisor length (mm) } \\
\text { maximum tail tip hair length (mm) } \\
\text { dorsal pelage reflectance (\%) } \\
\text { ventral pelage reflectance ( } \%)\end{array}$ & $\begin{array}{l}3 \\
3 \\
3 \\
3 \\
3 \\
3 \\
3 \\
3 \\
3 \\
3 \\
3 \\
3 \\
3 \\
3 \\
3 \\
3 \\
3 \\
3 \\
3 \\
3 \\
3\end{array}$ & $\begin{array}{c}102-110 \\
39-44 \\
7.40-7.86 \\
17.30-17.73 \\
16.78-17.34 \\
7.95-8.68 \\
3.13-3.48 \\
4.85=5.06 \\
12.60-12.82 \\
6.0-6.2 \\
6.7-6.9 \\
5.10-5.21 \\
64=70 \\
.35-.66 \\
.92-1.21 \\
.71-.79 \\
2.55-2.93 \\
0-1.6 \\
9.2-10.0 \\
13.3-18.0\end{array}$ & $\begin{array}{c}107.0 \\
41.7 \\
13.0 \\
7.683 \\
17.493 \\
17.087 \\
8.373 \\
3.270 \\
4.990 \\
12.690 \\
6.10 \\
6.80 \\
5.150 \\
67.0 \\
.467 \\
1.047 \\
.753 \\
2.730 \\
1.00 \\
9.53 \\
16.13\end{array}$ & $\begin{array}{l}4.36 \\
2.55 \\
0 \\
.2449 \\
.2121 \\
.7746 \\
.3754 \\
.1888 \\
.0992 \\
.1042 \\
.100 \\
.100 \\
.0354 \\
3.00 \\
.1683 \\
.1474 \\
.0404 \\
.1751 \\
.872 \\
.418 \\
2.495\end{array}$ & $\begin{array}{c}4.07 \\
6.12 \\
0 \\
3.19 \\
1.21 \\
4.53 \\
4.48 \\
5.77 \\
1.99 \\
.82 \\
1.64 \\
1.47 \\
.69 \\
4.48 \\
36.04 \\
14.08 \\
5.37 \\
6.41 \\
87.20 \\
4.39 \\
15.47\end{array}$ \\
\hline
\end{tabular}


TABLE XII

MORPHOMETRY OF SECOND-YEAR SHREWS FROM UPPER SAND ISLAND

\begin{tabular}{|c|c|c|c|c|c|}
\hline CHARACTER & $\begin{array}{l}\text { SAMPLE } \\
\text { SIZE }\end{array}$ & BANGF & MEAN & $\begin{array}{l}\text { STANDARD } \\
\text { DEVTATTON }\end{array}$ & $\begin{array}{c}\text { COEFFICIENT } \\
\text { OF VARIABILITY }\end{array}$ \\
\hline total length $(\mathrm{mm})$ & 4 & $96-109$ & 101.2 & 5.57 & 5.50 \\
\hline tail length $(\mathrm{mm})$ & 4 & $37-42$ & 39.8 & 2.08 & 5.23 \\
\hline hind foot length (mm) & 4 & $12-13$ & 12.5 & 1.00 & 8.00 \\
\hline body weight $(\mathrm{g})$ & 4 & $6.09-7.54$ & 6.672 & .6137 & 9.20 \\
\hline overall cranial length (mm) & 4 & $16.38-17.28$ & 16.935 & .4000 & 2.36 \\
\hline condylobasal length $(\mathrm{mm})$ & 4 & $16.03-16.78$ & 16.458 & .3109 & 1.89 \\
\hline maximum cranial breadth ( $\mathrm{mm}$ ) & 4 & $8.56-8.96$ & 8.712 & .1820 & 2.09 \\
\hline interorbital breadth (mm) & 4 & $3.21-3.37$ & 3.272 & .0658 & 2.01 \\
\hline maxillary breadth (mm) & 4 & $4.83-4.96$ & 4.885 & .0486 & .99 \\
\hline condyloinfraorbital length (mm) & 4 & $11.86-12.62$ & 12.328 & .3322 & 2.69 \\
\hline maxillary tooth row length (mm) & 4 & $5.6-5.8$ & 5.70 & .082 & 1.44 \\
\hline palatal length (mm) & 4 & $6.4-6.7$ & 6.58 & .126 & 1.91 \\
\hline cranial depth (mm) & 4 & $5.05-5.43$ & 5.292 & .1711 & 3.23 \\
\hline cranial weight (mg) & 4 & $56-67$ & 63.2 & 5.00 & 7.91 \\
\hline first upper incisor height (mm) & 4 & $.69-.99$ & .842 & .1301 & 15.45 \\
\hline first upper incisor length (mm) & 4 & $1.18-1.23$ & 1.200 & .0245 & 2.04 \\
\hline first lower molar height $(\mathrm{mm})$ & 4 & $.52-.71$ & .608 & .0781 & 12.85 \\
\hline first lower incisor length (mm) & 4 & $2.14-2.67$ & 2.398 & .2220 & 9.26 \\
\hline maximum tail tip hair length (mm) & 4 & & 0 & & 0 \\
\hline dorsal pelage reflectance (\%) & 4 & 0 & 9.05 & .480 & 5.30 \\
\hline rentral pelage reflectanc & 4 & 167 & & 2.041 & 10.94 \\
\hline
\end{tabular}


TABLE XIII

MORPHOMETRY OF SECOND-YEAR SHREWS FROM ILADY ISLAND

\begin{tabular}{|c|c|c|c|c|c|}
\hline CHARACTER & $\begin{array}{l}\text { SAMPLE } \\
\text { SIZE }\end{array}$ & RANGE & MEAN & $\begin{array}{l}\text { STANDARD } \\
\text { DEVIATION }\end{array}$ & $\begin{array}{l}\text { COEFFICIENT } \\
\text { OF VARIABILITY }\end{array}$ \\
\hline $\begin{array}{l}\text { total length (mm) } \\
\text { tail length (mm) } \\
\text { hind foot length (mm) } \\
\text { body weight (g) } \\
\text { overall cranial length (mm) } \\
\text { condylobasal length (mm) } \\
\text { maximum cranial breadth (mm) } \\
\text { interorbital breadth (mm) } \\
\text { maxillary breadth (mm) } \\
\text { condyloinfraorbital length (mm) } \\
\text { maxillary tooth row length (mm) } \\
\text { palatal length (mm) } \\
\text { cranial depth (mm) } \\
\text { cranial weight (mg) } \\
\text { first upper incisor height (mm) } \\
\text { first upper incisor length (mm) } \\
\text { first lower molar height (mm) } \\
\text { first lower incisor length (mm) } \\
\text { maximum tail tip hair length (mm) } \\
\text { dorsal pelage reflectance (\%) } \\
\text { ventral pelage reflectance (\%) }\end{array}$ & $\begin{array}{l}2 \\
2 \\
2 \\
2 \\
2 \\
2 \\
2 \\
2 \\
2 \\
2 \\
2 \\
2 \\
2 \\
2 \\
2 \\
2 \\
2 \\
2 \\
2 \\
2 \\
2 \\
2\end{array}$ & $\begin{array}{c}102-106 \\
43-44 \\
12-13 \\
7.47-8.04 \\
17.20-17.24 \\
16.84-16.88 \\
8.57-8.89 \\
3.33-3.44 \\
4.68-5.00 \\
12.50-12.56 \\
6.0 \\
6.7-6.8 \\
5.23-5.33 \\
64-67 \\
.77-.95 \\
1.10-1.27 \\
.69-.76 \\
2.64-2.67 \\
0.6-8.9 \\
14.9-17.6\end{array}$ & $\begin{array}{c}104.0 \\
43.5 \\
12.5 \\
7.755 \\
17.220 \\
16.860 \\
8.730 \\
3.385 \\
4.840 \\
12.530 \\
6.00 \\
6.75 \\
5.280 \\
65.5 \\
.860 \\
1.185 \\
.725 \\
2.655 \\
0 \\
8.75 \\
16.25\end{array}$ & $\begin{array}{l}2.83 \\
1.00 \\
1.00 \\
.4000 \\
.0566 \\
.0316 \\
.2102 \\
.0596 \\
.2209 \\
.0424 \\
0 \\
.071 \\
.0566 \\
2.24 \\
.1039 \\
.1202 \\
.0495 \\
.0212 \\
0 \\
.274 \\
1.924\end{array}$ & $\begin{array}{c}2.72 \\
2.30 \\
8.00 \\
5.16 \\
.33 \\
.19 \\
2.41 \\
1.76 \\
4.56 \\
.34 \\
0 \\
1.05 \\
1.07 \\
3.42 \\
12.08 \\
10.14 \\
6.83 \\
.80 \\
0 \\
3.13 \\
11.84\end{array}$ \\
\hline
\end{tabular}

